\title{
The Relative Importance of Regional Institutions and External Finance for Small Business Investment: Evidence from Vietnam
}

\author{
Bach Nguyen \\ nguyenb1@aston.ac.uk
}

Aston University, Aston Business School, Birmingham, UK, B47ET

\begin{abstract}
This study examines the relative importance of local institutions and external finance on small business investment. Utilising the institutional theory, we argue that local institutions and external finance have heterogeneous effects on firm investment. More importantly, they may interact and moderate each other. Analysing a set of 1.3 million observations of small businesses operating in Vietnam (2006-2016) obtained from the Annual Enterprise Survey data from the Vietnam Statistics Office, we find that local institutional settings and external finance are important determinants of firm investment. Moreover, local institutions are able to moderate the effects of external finance on firm investment. As such, this study asserts that conventional models cannot discern whether institutions or external finance are more important to firm investment. Rather, the relative importance of institutions and external finance should be investigated from the perspective of their interaction.
\end{abstract}

Keywords: Investment; Institutional settings; Informal loans; Local government; Vietnam JEL codes: D22; M13; P26

\section{Introduction}

A debate about whether it is the institutional setting or the availability of external finance that matters more for small business investment in developing countries was sparked by Johnson et al. (2002). Institutions are important to firm investment because they are directly related to the protection of private ownership in that they determine whether entrepreneurs can keep the fruits of their investment (Acemoglu and Johnson, 2005; Su et al., 2019). However, external finance also matters for investment because when bank credit is not available, it may be hard for small firms to realise business opportunities. The debate was fairly active for a time, with several works contributing to either the study of institutions (see Bruton et al. (2010) for a review) or the study of external finance (see Beck et al. (2008) for a review) in developing countries. However, a decade ago, 
debate petered out and the current literature rarely puts institutional variables and external finance variables in a theoretical framework to analyse their relative importance to small business investment.

Although the debate has stalled, the question 'are institutional settings or the availability of external finance more important to small business investment decisions in developing countries?' remains unanswered. This study aims to settle the matter by knitting two seemingly-unrelated strands of institutional and financial literature in order to modify the original theoretical framework employed by the previous studies. We do this in the following ways:

First, we go beyond formal institutions (laws and regulations) to include into the model informal institutions (local norms and practices of doing business) and institutions of governance (the governance quality of local governments). An investigation of local governance is essential because the formal institutional frameworks in developing countries are typically incomplete and underdeveloped; as such, their directives may not be fully, consistently, or efficiently enacted across a country's regions but are more likely to depend on the interpretation and enforcement efficiency of local government ( $\mathrm{Du}$ and Mickiewicz, 2016; Zhou, 2013). Also, it is crucial to investigate the informal institutions (business norms) because, given the weaknesses of the formal institutions, local business normative standards may operate as alternative "rules of the game" that shape firm behaviours (Williamson, 2000), including firm investment decisions.

For these reasons, it is arguably reasonable to expect that it is the surrounding institutional factors, such as local business norms and local governance arrangements, rather than the national formal institutions that are more relevant to small business investment.

Second, on the finance side of the model, we go beyond previous studies that use bank loans as the sole representative of external finance by taking into account informal credit (i.e., borrowing from relationship-based sources such as friends and family). This source of financing is essential to small businesses in developing countries, where equity markets such as venture capital, crowdfunding, and angel funds are largely unavailable or unpopular (Ayyagari et al., 2010). Informal finance is also important to small businesses because of the market failures associated with the formal financing sector (e.g., informational asymmetries) that restrict firms from obtaining sufficient bank loans to support their investment requirements (Carreira and Silva, 2010). For these reasons, it is unrealistic to assume that bank loans can be the sole means of accessing external finance for small businesses in developing countries. As such, we expect that by including informal finance into \ohnson et al. (2002) model, we can better explain small business investment decisions. 
Third, our model also accounts for the potential interaction effects between local institutions (i.e., local business norms and local governance quality) and external finance (i.e., bank loans and informal loans) in determining firm investment. This consideration is based on the recent literature showing that institutional and financial variables may not be independent of each other (Hartwell, 2017; Marcelin and Mathur, 2014). Hence, our argument that we cannot obtain a meaningful answer as to which of the two factors are more important to firm investment by naïvely comparing each to the other. In contrast, we suggest that the association between external finance and firm investment may change according to the local institutional settings.

Following McMillan and Woodruff (2002), we set our empirical context in Vietnam. The country has a transition economy boosted by a large number of small businesses, accompanied by renovated institutional and financial environments. We employ a panel of domestic private small businesses operating in Vietnam over 11 years (2006-2016) and use the general method of moment (GMM) approach to estimate regression coefficients on firm investment. ${ }^{1}$

The empirical findings show that external finance is associated with firm investment in different ways. Specifically, informal finance (relationship-based borrowing) is positively associated with firm investment, but bank loans are negatively associated with firm investment. We explain these effects via the lens of the institutional theory. Also, we find that entrepreneurs are keen to use more external finance (both formal and informal debts) in regions that have a more fully developed institutional environment. In other words, while entrepreneurs in less-developed institutional environments tend to substitute bank loans with profit investment, entrepreneurs in regions with 'strong' (conducive) institutional settings do the opposite: they complement their profit investment with bank loans to make higher-valued investment projects.

This study thus highlights the importance of local institutions (including both local business norms and governance quality) in facilitating firm investment either by reducing informational asymmetry and transaction costs $(\underline{\text { North, 1990) }})$ or by improving firm access to external finance ( $\underline{\mathrm{Cull} \text { and } \mathrm{Xu}}$, 2005).

\section{Literature and Hypothesis}

\subsection{Institutions and Firm Investment}

\footnotetext{
${ }^{1}$ Unlike previous studies in which the investment variable is constructed using firm financial statements, investment value in this study is directly reported by the surveyed small businesses.
} 
Institutions have been increasingly regarded as an essential determinant of entrepreneurship/small business activities and performance (Baumol, 2007; Bruton et al., 2010). Institutions are humanmade "rules of the game" which are typically classified into two general genres: informal institutions (norms, values, and beliefs) and formal institutions (rules, laws, and contracts) (Williamson, 2000). Better institutional quality is claimed to be conducive to economic activities by reducing transaction costs and informational asymmetries (Phuc Canh et al., 2019). While formal institutional settings (e.g., regulations concerning property rights protection) are widely discussed in the extant literature, the role of the informal institutions is less well understood. Stephan et al. (2015) point out that informal institutions may play a crucial but unexplored role in shaping the economic activities and performance of social agents.

In this study, we suggest that, within a relatively homogenous and stable national formal institutional setting (i.e., national constitutional and regulatory frameworks), heterogeneity in the informal institutions may play an essential role in determining firm investment decisions. As can be seen in the case of Vietnam, the effect of informal institutions may present via a specific historical event. The economic system in North Vietnam never deviated from the pure socialist blueprint, whereas South Vietnam was capitalist up until 1975. This political separation gives rise to significant differences in the two regions' entrepreneurial norms, values, and beliefs (Makino and Tsang, 2011). Moreover, these norms of doing business, akin to those in East and West Germany (Fritsch and Storey, 2014), are expected to continue despite the two states having unified four decades ago when a common framework of formal institutions was established for the whole country. As such, in line with previous studies (Canh Phuc et al., 2018; Nguyen et al., 2018), we assume that the norms of doing business in South Vietnam (once exposed to capitalism) are more entrepreneurship-friendly than the norms of doing business in North Vietnam (pure socialism).

Accompanying the local norms of doing business is the governance quality of local governments. Williamson (2000) suggests that the 'play of the game' by the institutions of governance indicates the pragmatic application at local level of the 'rules' laid down by the formal institutions. The governance quality of local governments is crucial because it has the power to reshape the rewarding structures (De Castro et al., 2014; Nguyen et al., 2018). This is particularly the case in developing postcommunist economies, where formal institutions are incomplete and underdeveloped, leaving ample room for local authorities to interpret and manipulate central laws according to their own understanding or, even worse, for their own benefit (Chien and Kezhong, 2012). As such, in this study, we propose local governance as an important institutional determinant of small business investment. 
It is noteworthy that, in comparison to the relatively fixed national constitutional configurations, local governance quality is relatively flexible and can react nimbly to changing circumstances. Also, local governance can work to reduce institutional liabilities such as the requirement to follow illegitimate norms (e.g., proffer bribes) for survival. In other words, local governance is conducive when it eases off the burden of conducting activities that conform to local norms but hamper efficiency. For this reason, the effect of local governance on firm investment may be stronger in those regions where the local norms of doing business provide little support for entrepreneurship (e.g., pure socialism). The reason underlying this expectation is that the marginal effects of an improvement in local governance quality are enhanced when the local business norms are unfriendly to entrepreneurship (․ㅡㄹen et al., 2018).

The first such marginal effect can be seen in the effect of reducing local transaction costs. Small businesses located in regions that have business norms obstructive to entrepreneurship (e.g., corruption) may find that the creativity and cleverness of local authorities in implementing central policy and in designing their own initiatives for local private sector development is key to reducing transaction costs (Malesky et al., 2015). This reduction in transaction costs may then lead to a stronger incentive for investment. In contrast, when the local business norms are friendly to entrepreneurship ex-ante, the level of local transaction costs will be relatively low so local small businesses may already have invested to maximum effect. As such, an improvement in local governance quality may have little further impact on boosting firm investment.

The second marginal effect is the effect of an improvement in perceived governance efficiency (Efendic et al., 2015). Improved local governance quality has less influence on firm investment in regions with conducive norms of doing business because entrepreneurs are operating within favourable institutional environments (e.g., there is less corruption). When an entrepreneurshipfriendly institutional setting is taken for granted, a further improvement in local governance may have only a modest impact on entrepreneurs' perception of the surrounding environments and thus exerts little influence on their investment incentive (Busenitz et al., 2000). In contrast, in regions hampered by entrepreneurship-unfriendly business norms, small businesses may find that an improvement in local governance quality will substantially reduce the burdens of operating under local negative norms (e.g., bribes) (Holmberg et al., 2009). This positive perception may boost their incentive to invest in new projects. Therefore, we suggest the following hypothesis:

Hypothesis H1: In Vietnam, the effect of local governance quality on firm investment is stronger in regions endowed with entrepreneurship-unfriendly norms of doing business. 


\subsection{External Finance and Firm Investment}

\subsubsection{Bank Loans}

The role of bank loans as an external financing source of firm investment has been widely examined in the extant finance literature (Cumming and Johan, 2017). There is a consensus that firms will seek out bank loans only when their internally generated funds (e.g., retained earnings) are insufficient to support investment demand (Vanacker and Manigart, 2010). The pecking order theory suggests that informational asymmetries (which cause moral hazard and adverse selection) may increase the risks for external lenders (Myers, 1984). Because the costs of solving these market failures are high in that lenders must obtain and evaluate all relevant information about a business before making a lending decision, banks are likely to require a higher rate of return to make up for the potential risks of funding small businesses ( of financing that is considered only after entrepreneurs' internal funds have been exhausted. However, in developing countries (Vietnam being the context of this study), bank loans may not even be a secondary source of funding, for the following reasons.

First, underdeveloped conditions and frictions in the financial markets in Vietnam may induce significant informal costs for small businesses wishing to gain access to bank loans. For example, Le et al. (2019) investigating a set of Vietnamese state-owned banks, conclude that the banking reforms adopted in Vietnam are discriminatory in that they operate against domestic private and foreignowned banks. The resulting distortions and inefficiencies in the banking sector have the potential to adversely impact on the borrowing incentives of local small businesses. Also, Lainez (2014) finds evidence showing that informal credit is perceived by Vietnamese borrowers as an economic necessity for their venturing activities. This is due to the high transaction costs (including the length of time the application process takes) of obtaining bank loans (guyen and van den Berg, 2014). Therefore, it could be expected that in Vietnam, small businesses will mostly rely on informal debt, which translates into a negative association between firm investment and formal bank loans.

Also, since the relationship-based principle plays a significant role in lending transactions, small firms may self-select out of the formal financial market (Du et al., 2015). Specifically, Nguyen et al. (2006) find that in the absence of effective market-based and arm's-length principles, banks in Vietnam do not so much face risk as considerable uncertainty when lending to private businesses. Consequently, (state-owned) banks largely rely on relationships and trust when evaluating applications and making lending decisions. This relationship-based borrowing strategy is usually associated with substantial networking costs for those firms that wish to establish and maintain 
social capital with officials ( possess insufficient resources to support even their day-to-day operations, may find themselves incapable of playing the costly game of networking (Sarah and Phuong An, 2005), leading to them writing off bank loans as a means of funding their activities, including their investment projects.

Further, the institutional systems in Vietnam in particular and in developing countries in general may be inadequately strong to persuade entrepreneurs that their private properties can be protected from appropriation (Canh Phuc et al., 2018). Insecure property rights protection thus reduces the efficiency of government, leading to a situation where entrepreneurs use external finance for their investment projects while redirecting their earned profits to other safer channels ( $\underline{\mathrm{Cull}}$ and Xu, 2005). Specifically, Jiang and Zeng (2014) show that there is a negative relationship between the use of bank loans and the ratio of profit investment in China because of the high risk of appropriation and the ineffectual laws concerning property rights. Also, Zhou (2013) demonstrates that when entrepreneurs gain more confidence in the political system, they are willing to increase their rate of investment rather than redistributing a large proportion of their profits. In Vietnam, since the financial systems are underdeveloped and the formal institutional frameworks are incomplete, entrepreneurs running small businesses may not consider it wise to re-invest their profits (unless they have other financing options) (Nguyen, 2019), and indeed, if entrepreneurs do obtain bank loans, they may correspondingly reduce the amount of profit reinvested (which is a proportion of the firm investment that is under investigation in this study), leading to reduced overall investment values. In sum, we suggest the following hypothesis:

Hypothesis H2a: In Vietnam, formal finance (in terms of bank loans) is negatively associated with firm investment.

\subsubsection{Informal loans}

Small businesses in developing countries largely rely on informal debts to grow (yyyagari et al., 2010; Wu et al., 2016). In this study, following the most recent literature (Karaivanov and Kessler, 2018), informal finance is defined as borrowing from relationship-based financing sources (i.e., family and friends). ${ }^{2}$ Beck et al. (2015) argue that informal finance plays an essential role in developing countries, where equity markets (e.g., venture capital, angels, and crowdfunding) are largely underdeveloped and unpopular. Informal finance also serves as a complement to bank loans

\footnotetext{
2 Our definition of informal finance is more specific than the old definition that encompasses all financing sources save for bank loans (Allen et al., 2005; Cull and Xu, 2005; McMillan and Woodruff, 2002).
} 
(Ayyagari et al., 2010). Because of market failures, small businesses suffer from a situation where the demand for funds is greater than supply (credit rationing). Informal finance may alleviate this funding gap by providing small firms with a source of low-cost, relationship-based capital (Beck et al., 2008). As such, informal finance has been found to have a positive association with firm performance, especially in developing countries (Beck et al., 2015).

In contrast to bank loans, we expect that informal debts are positively associated with firm investment. Even though the two credit sources are forms of external financing, informal loans are entirely relationship-based ( $\underline{\mathrm{Wu} \text { et } \mathrm{al} ., 2016})$. The advantage of the 'relationship' in this type of lending transaction could be a lower required rate of return and a longer repayment period (Karaivanov and Kessler, 2018). However, the disadvantage lies in the implicit burden of repayment (which Adomdza et al. (2016) term an unlimited liability contract). Even though the repayment conditions in informal finance are usually not legally contracted, they are by no means less binding to entrepreneurs because of the following reasons.

First, accessing informal finance is directly related to entrepreneurs' networks, which are worth maintaining (Lee and Persson, 2016). Entrepreneurs regard bank loans as 'weak-tie' (arm's-length) business transactions, which are completely separate from their personal life. They therefore view defaulting in repaying a bank loan as something that only affects their business activities. In contrast, relationship-based borrowing is concerned with their personal networks. A default in repaying informal loans may completely ruin 'strong-tie' (emotion-based) personal relationships (Bertrand and Schoar, 2006). A loss of 'strong-ties' social capital is perceived (by entrepreneurs) as being far more costly than defaulting in paying 'weak-ties' bank loans ( Karaivanov and Kessler, 2018). Also, entrepreneurs are inclined to treat relationship-based borrowing as a form of 'internal' funding (Gartner et al., 2012; Lee and Persson, 2016). Because of the relationship effects, the personal responsibility of entrepreneurs is strongly attached to such informal borrowing. Thus, instead of secreting their profits away, entrepreneurs have an incentive to increase their investment values as a means of securing future repayment.

In addition, the costs of losing 'strong-ties' relationship-based financing sources are relatively high. Entrepreneurs understand that if they fail to repay their friends and family, they will be cut off from that form of financial support in the future (Chua et al., 2011). Given that other external financing sources are more difficult to access and probably more expensive, entrepreneurs may decide to boost their commitment to their businesses' investment projects in the hope that investing will improve the likelihood of successful repayment. Therefore, we suggest the following hypothesis: 
Hypothesis H2b: In Vietnam, informal finance (in terms of relationship-based borrowing) is positively associated with firm investment.

\subsection{Institutions and External Finance}

While previous studies examine external finance and institutions as two mutually exclusive determinants of firm investment decisions, we suggest in this study that they may have a shared effect in that institutional settings are able to moderate the choice of external financing sources. Figure 1 shows the moderation effect that forms our next hypotheses. In general, it is expected that firms located in regions endowed with developed institutional settings obtain more external financing, including both bank loans and informal loans. To explain the mechanisms underlying this expectation, we utilise two strands of literature; the first being the transaction cost perspective and the other the theory of cognitive financial constraints. These two theories can be used to explain the moderating effects of institutions on both the supply and demand sides of the financial markets.

$<$ Figure 1 inserts here>

\subsubsection{Supply-side}

Regions with norms conducive to doing business usually enjoy a lower average level of transaction costs because entrepreneurs are keen to formalise transactions into legal contracts in order to gain the benefit of property rights protection (Nguyen et al., 2018; Williamson, 1985). The legitimacy of arm's-length principles rather than those based on relationships significantly reduce the costs of negotiating and monitoring business lending transactions, thus creating a more effective banking market. When transactions are legally binding, banks are less troubled by the potential agency costs and moral hazard risks, which would be a serious concern in relationship-based transactions due to the opacity of information (Allen et al., 2005). In pro-entrepreneurial regions, banks are keen to offer loans to small businesses (that would otherwise endure credit rationing) and even reduce the required rate of return (Johnson et al., 2002). As such, it is expected that regions with conducive business norms will see an expansion in the local supply of bank loans.

Further, a set of conducive business norms may facilitate the supply of informal loans, thanks to efficient enforcement by the normative institutional forces. Specifically, in regions where the level of business norms is strong, social agents tend to believe that others will play by and respect the same 'rules' as they do (Efendic et al., 2015). Thus, informal creditors may perceive that the risks of making unsecured loans are lower (since they believe borrowers will abide by the norms), and they may 
therefore reduce the required rate of return and increase their lending, a decision that would be less likely to occur in regions with weak business norms.

High-quality local governance may also reduce transaction costs and facilitate the local supply of finance. When local governance quality improves, commercial banks will have more confidence in the effectiveness of government agents and their reliance on local law-enforcement systems to protect their legal rights (Nguyen and van Dijk, 2012). Improved governance quality also reduces the costs of screening and selecting borrowers because information is made transparent by the government (Nguyen et al., 2018). As such, banks operating in regions with high-quality governance systems can more confidently serve small businesses.

In general, we propose that the supply of finance in regions endowed with developed institutions (in terms of local governance and business norms) is higher than the supply of finance in regions endowed with institutions that are less well-developed.

\subsubsection{Demand-side}

Business norms may influence not only the supply of but also the demand for external finance (Barton and Gordon, 1987). A set of pro-entrepreneurship business norms that includes innovativeness, proactiveness, and creativity is likely to push entrepreneurs to pursue ambitious goals of growth, leading to a higher level of demand for capital investment, (Baron, 2007). Also, in such an active entrepreneurial environment, firms are forced to compete with each other for limited access to external funding ( $\underline{\left.0^{\prime} T o o l e ~ e t ~ a l ., ~ 2016\right) . ~ F o r ~ t h i s ~ r e a s o n, ~ s m a l l ~ f i r m s ~ m a y ~ a c c e p t ~ a ~ h i g h e r ~ i n t e r e s t ~ r a t e ~}$ to gain their desired values of loans.

Meanwhile, as was pointed out in the previous section, financial suppliers in developed institutional environments tend to reduce the required rate of return when they perceive that the risk of a lending transaction is lower. As the demand and supply of external finance converge towards an equilibrium where the local norms of doing business are conducive, local financial markets would become more effective.

Besides business norms, the governance quality of local governments may also exert a positive impact on firms' demand for capital for two reasons. First, high-quality governance reduces the perceived institutional uncertainties, which are the origin of entrepreneurial cognitive (motivational) constraints in financing (Ahunov and Yusupov, 2017; Fraser et al., 2015). Also, a set of strong and inclusive governance arrangements reduces the perceived risk of appropriation, boosting firm investment. 
Second, a set of high-quality governance arrangements may exert an effect similar to that produced by conducive business norms by introducing growth aspirations to local entrepreneurs (Fritsch and Storey, 2014). Local governance arrangements, if consistently constructive to entrepreneurship, are able to function like informal institutions (i.e., they create new values and beliefs) in enabling and nurturing positive norms in doing business. Nguyen et al. (2018) find that authorities in regions that exhibit a low level of social acceptance of entrepreneurship can facilitate entrepreneurial activities by improving local governance quality.

In general, we propose that well-managed business norms and local governance may, on the one hand, increase financial supply by reducing transaction costs. On the other hand, they may reduce entrepreneurs' cognitive (motivational) constraints in seeking external finance (Cressy and Olofsson, 1997). Since both the demand and supply of external finance increase in developed institutional environments, we propose the following hypotheses:

Hypothesis H3a: The negative association between bank loans and firm investment (proposed in $\mathrm{H2a}$ ) will become positive in regions having more developed governance quality/business norms.

Hypothesis H3b: The positive association between informal finance and firm investment (proposed in $\mathrm{H} 2 \mathrm{~b}$ ) will become stronger in regions having more developed governance quality/business norms.

\section{Data and Method}

\subsection{Data}

The empirical setting of this study is Vietnam. To test the proposed hypotheses, we employ the Annual Enterprise Survey dataset provided by Vietnam's General Statistics Office (GSO). The survey was first conducted in 2000 and the dataset is updated annually. By regulation, all businesses having more than 10 employees are required to participate in the survey. For businesses with fewer than 10 employees, a sample is randomly selected to participate in the survey. The dataset provides comprehensive information about firm financial characteristics, employment, investment, and performance. The scope of the survey comprises both the manufacturing and service industries and all forms of business ownership. The panel data obtained from GSO covers 16 years, from 2000 to 2016. However, the period of analysis in this study is scaled down to 11 years, i.e., from 2006 to 2016, to match with the second dataset, the Provincial Competitiveness Index (PCI). 
This Index is a panel of provincial governance quality, jointly produced by the Vietnam Chamber of Commerce (VCCI) and the US Agency for International Development (USAID). Governance quality is scored from 0 to 100 , with higher scores reflecting better governance quality. The PCI index is calculated based on a survey of more than 17,000 domestic firms and 1,700 foreign firms in Vietnam. The pilot study was conducted in 2005 on one-third of Vietnam's provinces. In 2006, the PCI index became available for all 63 provinces and it is updated annually.

We combine the firm-level GSO dataset with the provincial level PCI dataset to create a multi-level panel of 11 years, from 2006 to 2016 . While the PCI panel is strongly balanced, the GSO dataset is unbalanced, with some firms performing exceptionally better or worse than the average. We control these outliners by censoring the top and bottom $1 \%$ of observations in each variable. Details about the panel structure of our dataset are reported in Appendix 1.

Our population of interest in this study is micro-firms and small and medium-sized enterprises (SMEs). We are not interested in large corporations for two reasons. First, large firms are less sensitive to local government quality because, unlike small businesses, they are not bounded to any particular local market (Nguyen et al., 2018). In addition, they are less financially constrained and less likely to have to rely on informal loans (Carreira and Silva, 2010). We also exclude state-owned firms because their operations may not follow market principles and they are prohibited from using informal loans (Zhou, 2017). Nor do we do count foreign-owned firms because they enjoy several special treatments from central government, which may distort their sensitivity to local governance quality (Chien and Kezhong, 2012). The final sample in our study thus contains 1,335,157 observations of domestic private micro-firms and SMEs. ${ }^{3}$

\subsection{Variables}

The dependent variable of interest in this study is investment, which is the ratio of the value of firm investment to total capital. In previous studies, the investment rate of listed corporations has been calculated using financial statements. However, in this study, the investment rate is self-reported by small businesses in a survey question: 'How much is the total amount of profits that your company

\footnotetext{
${ }^{3}$ According to the Vietnam Enterprise Law, there are four types of firm size. Micro-enterprises are firms operating with fewer than 10 employees. Small enterprises are firms that have 10 to 200 employees and total registered capital of less than 20 billion VND (approximately 1 million USD). Medium enterprises are firms with 200-300 employees and total registered capital of less than 100 billion VND (approximately 5 million USD). Large enterprises are firms with more than 300 employees and 100 billion VND registered capital. Capital is the first criterion in categorisation.
} 
reinvested plus the amount of additional external finance and personal wealth that you newly invested in your business?'4 Using this item, our dependent variable captures both profit investment and any additional debt and equity investment. Thus, our investment variable is better able than the conventional investment variable to measure the strength of the commitments entrepreneurs put into their businesses.

To measure the effect of external financing, we employ two variables: bank loans and informal loans. While Cull and Xu (2005) employ a dummy variable to indicate whether or not firms use bank loans, we use the values of bank loans and informal loans, which could better measure the quantity of external finance. Specifically, the Bank loans variable is the ratio of the value of a firm's bank loans for investment purposes to its total capital. The Informal loans variable is the ratio of the value of borrowing from family and friends for investment purposes to total capital. Table 1 shows the definitions of and summary statistics for the variables. The average investment rates are $28 \%$ of total capital while average bank loans are $6 \%$ and informal loans are $2 \%$ of total capital. These statistics indicate that small businesses in Vietnam still largely rely on their owner-managers' personal wealth for investment despite the recent reforms of the banking system (Nguyen et al., 2016).

\section{$<$ Table 1 inserts here $>$}

Besides external financing, we are also interested in the effect of institutional environments on firm investment. We measure business norms (informal institutions) using a dummy variable: South, which takes value 1 if a firm is located in South Vietnam, and 0 if a firm is located in North Vietnam. ${ }^{5}$ This variable is able to gauge the differences in values, beliefs, and norms of doing business between two regions whose differences chiefly arise from a historical event (Nguyen et al., 2018). Specifically, South Vietnam was essentially a capitalist state prior to its transformation to socialist in 1975 when it unified with North Vietnam. South Vietnam was therefore exposed to a set of pro-entrepreneurship values, such as independence, risks-acceptance, and arm's-length principles (Makino and Tsang, 2011).

Meanwhile, North Vietnam strictly followed a pure socialism blueprint, which emphasises the importance of values such as interdependence, risk-avoidance, and relationship-based principles (Shultz et al., 2000). These values, however, are inimical to the development of

\footnotetext{
${ }^{4}$ Both the amounts of reinvested profits and additional equity are reported for the same year.

${ }^{5}$ The official division of the North and South states in the French Indochina War was determined by the 17th parallel. The boundary between these two states was established at the Ben Hai River, which enters the South China Sea at 17 degrees 0 minutes 54 seconds $N$ latitude (Makino and Tsang, 2011).
} 
entrepreneurship/private small businesses. Even though it has been four decades since the two states unified and propagated a common formal institutional system, it is our expectation that, according to the institutional theory (Williamson, 2000), the differences between the two regions' norms of doing business will remain (Nguyen et al., 2018).

Another institutional variable is local governance quality. To measure the governance quality of local governments, we use the PCI index. This index is a combination of nine sub-indices, each of which evaluates a dimension of local government. They include controls for corruption, levels of transparency in public services, and the leadership proactivity of local authorities. Details of the nine sub-indices are presented in Appendix 2. The PCI score ranges from 0 to 100; the higher the score, the better the quality of government. Over the study period, the average PCI score is 60. Specifically, the average PCI score for provinces in the South is 61.8, while the average PCI score for provinces in the North is 57.7. These statistics initially indicate that governance quality in the South is, on average, better than it is in the North.

Following the extant literature, we include a set of covariates that may influence firm investment. At the firm-level, we control for firm size, firm age, and industry. These variables represent firm-specific and industry-specific characteristics, which significantly determine the rate, value, and frequency of investment (Zhou, 2017). At the entrepreneur-level, we control for owner age, gender, and education. These individual-specific factors play an essential role in investment decisions because they indicate the knowledge and experience of entrepreneurs, which may distinctly influence their ability to recognise and evaluate business opportunities (Tran and Santarelli, 2014). At the provincial level, we include the following variables: population density and consumption value per capita (to control for local market demand), labour force (to control for local labour supply), and distance from a province to the closest municipal city (business and political centres) to take into account the interaction among provinces (Nguyen et al., 2018). These regional economic factors may shape local business environments, which subsequently determine firm investment decisions. The definitions and summary statistics of these variables are presented in Table 1. The correlation coefficient matrix is presented in Appendix 3.

\subsection{Specification and Estimation}

Based on the conventional firm investment model (Cull and Xu, 2005; Zhou, 2017), we propose an expanded reduced-form investment equation. This is our baseline specification: 
(1) Investment ${ }_{\text {igt }}$

$$
\begin{aligned}
& =\beta_{0}+\beta_{1}\left(\text { Firm controls }_{i g t}\right)+\beta_{2}\left(\text { Owner controls }_{i g t}\right)+\beta_{3}\left(\text { Province controls }_{g t}\right) \\
& +\beta_{4}\left(\text { Business norms }_{g t}\right)+\beta_{5}\left(\text { Local governance quality }_{g t}\right) \\
& +\beta_{6}\left[\left(\text { Business norms }_{g t}\right) \times\left(\text { Local governance quality }_{g t}\right)\right] \\
& +\beta_{7}\left(\text { Informal loans }_{i g t}\right)+\beta_{8}\left(\text { Bank loans }_{i g t}\right)+v_{j}+v_{t}+v_{i}+\mu_{i t}
\end{aligned}
$$

where $i$ denotes an individual firm, $g$ is the province, and $t$ a year. Therefore, (Investment igt $_{\text {) }}$ is the investment rate that firm $i$ in province $g$ makes in year $t$. The term Firm controls igt $_{\text {is comprised of }}$ two variables: firm age and firm size. The term Owner controls $s_{i g t}$ includes owner age, owner gender, and owner education variables. Province controls $_{g t}$ constitutes local consumption power, population density, labour force supply, and distance from a province to the closest municipal city. Business norms $_{g t}$ is the South dummy, and the term Local governance quality gt $_{\text {is }}$ the PCI score. As such, the term Informal institutions ${ }_{g t} \times$ Local governance quality $_{g t}$ indicates the interaction between the two levels of institutions. Finally, the terms Bank loans igt $_{\text {and Informal loans }}$ igt are the two external financing sources.

According to the institutional theory, $\beta_{4}$ and $\beta_{5}$ are expected to be positive because small businesses operating in favourable institutional environments have a stronger incentive to make investment (Nguyen et al., 2018). We are particularly interested in the coefficients $\beta_{6}, \beta_{7}$ and $\beta_{8}$. Since local governance may be more important in regions that are less entrepreneurship-friendly, it is expected that $\beta_{6}$ will be negative. In other words, the effect of local governance on firm investment will become weaker in regions that have pro-entrepreneurship business norms. Regarding the external financing variables, we expect $\beta_{7}$ to be positive because of the implicit burden of repayment to family and friends. Meanwhile, $\beta_{8}$ is expected to be negative since entrepreneurs in Vietnam may choose to substitute profit investment with bank loans to avoid the risks of appropriation.

To test the moderation effects of institutions on financing sources, we propose the following interaction terms: Business norms $s_{g t} \times$ Bank loans $_{i g t} ;$ Business norms $_{g t} \times$ Informal loans $_{\text {igt }}$; Local governance quality $_{\text {gt }} \times$ Bank loans $_{i g t}$; Local governance quality git $\times$ Informal loans $_{\text {igt }}$. We expect the coefficients associated with these interaction terms to be positive because external financial markets are likely to function more efficiently in stronger institutional environments.

Also, the investment equation includes an industry-specific component $v_{j}$, and a time-specific component $v_{t}$, which are controlled by corresponding dummies. The term $v_{i}$ represents all time- 
invariant firm-specific factors that may influence firm investment. Finally, $\mu_{i t}$ is the idiosyncratic error.

We employ the system general method of moment (GMM) to estimate the regression coefficients. The GMM approach could deal, to some extent, with potential endogeneity in our model. Specifically, the two institutional variables (business norms and local governance quality) may be endogenous because a small business boom may force local governments to improve governance quality; it may even gradually alter the local norms of doing business, leading to a reverse effect from firm investment to institutional settings (Nguyen et al., 2018). Also, by the same argument, firm investment may prompt the local financial markets to renovate and function more efficiently (Ayyagari et $\mathrm{al}_{.}, 2010$ ). As such, we treat the four dependent variables (business norms, local governance quality, bank loans, and informal loans) and firm size as endogenous variables. GMM addresses this potential endogeneity by treating the lagged terms of endogenous variables as valid instrumental variables. Specifically, in the difference equations, we use the lagged 3- to 4-year terms to instrument the endogenous variables. The specification tests suggest that this length of lag is sufficiently deep to reduce correlation between the endogenous variables and the error terms while, at the same time, remaining sufficiently relevant to the current terms of the endogenous variables for them to remainvalid instrumental variables. The system GMM, moreover, corrects any possible finite sample bias by omitting informative moment conditions through the use of differences as instruments for level equations. In level equations, we use the difference of endogenous variables lagged 2- to 3-years as valid instruments. Finally, we conduct two specification tests: a second-order autocorrelation test of $\mathrm{AR}(2)$ in the transformed equations to examine whether the level equations are serially correlated at order 1; and the Hansen (J) test of the overidentifying restrictions.

\section{Results}

\subsection{Main Results}

The regression results are presented in Table 2. Columns 1, 2, and 3 test the effect of the institutional variables while columns 4,5 , and 6 examine the effect of the external financing variables. The specification tests suggest that there is no serious issue with our modelling. The coefficients associated with business norms and local governance are positive and statistically significant, confirming the validity of the institutional theory. More importantly, the coefficients associated with the interaction term between business norms and local governance in columns 3 and 6 are negative and statistically significant. This finding indicates that the effect of local governance is stronger in 
regions that have less well-developed business norms (i.e., North Vietnam). As such, this result confirms our hypothesis 1.

$<$ Table 2 inserts here $>$

Regarding the external financing sources, the results in columns 4, 5, and 6 show that the coefficients associated with bank loans are negative while the coefficients associated with informal loans are positive. This finding demonstrates the substitute effect of bank loans and the complementary effect of informal loans on firm investment. Evidently, small firms decide to increase their investment values when they obtain informal loans, probably because they want to secure repayment for their friends and family. Meanwhile, under a less developed institutional environment that is associated with unsecured property rights, small firms in Vietnam are keen to substitute profit investment by bank loans. This finding indicates that the association between firm investment and external financing is not homogeneous but depends on the nature of the financing sources. As such, our hypotheses $2 \mathrm{a}$ and $2 \mathrm{~b}$ are supported.

Table 3 shows the regression results of the interaction terms. The coefficients associated with the interaction terms between the institutional variables and external finance variables are all positive and statistically significant. This finding indicates that the effects of external financing on firm investment are stronger when local institutions improve. To examine the effects in more detail, we separately estimate the marginal effect of each interaction term. The results are presented in Figure 2 to Figure 5.

$<$ Table 3 inserts here>

$<$ Figure 2 to Figure 5 insert here $>$

Figures 2 and 3 show the marginal effects of business norms on bank loans and informal loans, respectively. It is noteworthy that the relationship between bank loans and firm investment is, on average, negative. However, this negative relationship becomes positive in regions that have more pro-entrepreneurship norms of doing business (i.e., regions in South Vietnam). In these regions, the local norms of doing business are more favourable to small business investment, leading to an increase in both the demand for and supply of credit. In contrast, in North Vietnam, entrepreneurs are keen to substitute profit investment by bank loans, leading to a lower value of investment.

A similar effect is found in Figure 2. The relationship between informal loans and firm investment is positive on average. However, this positive effect is stronger in South Vietnam. In general, the two 
figures demonstrate that a set of conducive business norms can boost firms' use of external finance to undertake higher-value investment projects.

Similarly, Figures 3 and 4 show the marginal effects of local governance on bank loans and informal loans, respectively. The results are consistent with the findings on business norms. Specifically, local governance, when it reaches sufficiently high quality, can reverse the substitution effect of bank loans. Also, local governance quality can strengthen the positive association between informal loans and firm investment.

\subsection{Robustness Checks}

\subsubsection{Firm Profitability}

Since the investment amount is funded by a combination of reinvested profit, external finance, and new equity (additional personal wealth from the owners), profitable firms would have more opportunities to make investments while loss-making firms may have to use more of the owners' money to fund their investments. This implies potential differences in the financing strategies between the two groups of firms.

Appendix 4 presents the regression results on the two sub-samples. The results show that firms with financial losses face difficulties in gaining access to bank loans while profit-making firms may find bank loans a complementary source of finance to support their investments (the coefficients associated with bank loans turn positive in columns 7 and 8). Also, entrepreneurship-friendly business norms only affect the profitable firms; loss-making firms do not respond to this institutional force. However, the results show that a set of conducive institutional arrangements, including both local governance quality and informal norms, significantly boosts the use of external finance and thus enhances firm investment values (the coefficients associated with the interaction terms are all positive and statistically significant). As such, we conclude that while firms with dissimilar levels of profit performance may employ different financing strategies and respond differently to the surrounding institutional settings, improved institutional settings will benefit all types of firms.

\subsubsection{Alternative Separation of Business Norms}

Following the extant literature, we measure business norms using a dummy variable that distinguishes between the norms in North and South Vietnam that derive from the differing historical and political patterns of the two regions. However, business norms in Vietnam may also have their roots in the French colonial period (1863-1945). Before the Americans separated the country into North and South, the French had divided Vietnam into three independent countries: Tonkin (Bac Ky); 
Annam (Trung Ky); and Cochinchine (Nam Ky). While Tonkin and Annam were protectorates independent countries protected by the French government - Cochinchine was a colonie, i.e., a region that completely belonged to capitalist France (Aldrich, 2014). For this reason, it could be expected that Cochinchine's norms are more conducive to business. It is also noteworthy that Cochinchine was a sub-region of South Vietnam (Dell et al., 2018) and, as such, the region arguably has the strongest business norms in Vietnam.

The regression results are presented in Appendix 5. Tonkin (Bac Ky) is employed as the benchmark. The results show that firms in Tonkin invest more than firms in Annam (Trung Ky), but less than firms in Cochinchine (Nam Ky). Also, the effect of local governance is strongest in Annam and weakest in Cochinchine. More importantly, the results indicate that business norms in Cochinchine significantly improve firm access to both formal and informal loans. Business norms in Annam also help firms obtain more bank loans. The findings imply that Tonkin's business norms are relatively weak compared to the other regions so far as facilitating firms to borrow external finance is concerned.

\subsubsection{Alternative Measures of Business Norms}

Due to the lack of direct measures of informal institutions in the context of Vietnam, we employ in this study a set of geographical dummy variables as a proxy for the different business norms prevailing in the north and south of Vietnam. To ensure the robustness of the findings, we also strive to replicate the regressions using some direct measures of business norms. Specifically, we propose the use of (1) the number of traditional food markets and (2) the number of cargo transportations as a proxy of entrepreneurship-friendly business norms. We have chosen these variables because proentrepreneurship norms may significantly encourage regional economic activities and transactions (Nguyen et al., 2018). Hence, the dynamism of local businesses may be employed as a measure of the existence and the degree of pro-entrepreneurship norms. Appendix 6 presents the regression results using the number of traditional markets and the number of cargo transportations within a region (north/south) as the alternative measures of pro-entrepreneurship norms. The results are in general consistent with our main findings and support the proposed hypotheses.

\subsubsection{Macro Conditions}

The period of study includes the 2008 financial crisis, which put commercial banks into difficulties with higher non-performing loans, and high interest and inflation rates. These specific conditions may have influenced bank lending decisions and affected firm financing and investment. To control 
for these macro-economic conditions, following Guariglia and Liu (2014) and Carpenter and Petersen (2002), we include a set of interaction terms between the year and province dummies (on top of their individual dummies). These interaction terms account for unobservable time-variant economic conditions at the local level. Also, we include another set of interaction terms between year and industry dummies (on top of their individual dummies) that account for unobservable time-variant economic conditions at the industry level. The regression results with these additional controls are presented in Appendix 7 and are consistent with our main specifications.

Moreover, we examine the two sub-samples: before and after the crisis. The regression results are presented in Appendix 8. The results show that our findings are more consistent in the post-crisis period while there is no clear pattern in the pre-crisis period.

\section{Discussion and Conclusion}

This study investigates the relative importance of local institutional environments and external finance to the investment decisions of small businesses. Our key research objective is to examine the moderation effects of local institutions on the financing strategies of firms. This study thus resurrects the literature analysing the factors that determine firm investment decisions in developing countries (Cull and $\mathrm{Xu}, 2005$ ). Specifically, it provides a potential answer to the long-debated question of whether it is the institutional setting or access to finance that is more important to small business investment (Johnson et al., 2002; McMillan and Woodruff, 2002).

While the relative importance to firms of institutions and external finance has previously been examined, the novelty of this study lies in its analysis framework which has been expanded in both the institutional dimension and the financing dimension. Specifically, in terms of institutions, we examine local informal institutions and governance quality, which are both claimed to be essential to boosting firm investment. In addition, in terms of external finance, we investigate both formal and informal financing sources. More importantly, in addition to these expanded factors, we analyse the moderation effects between institutional forces and the sources of external finance.

This study's findings show that both factors are crucial, but it would be inappropriate to analyse their individual effects. We argue instead that institutional environments and external finance are interlinked and that the effect of external finance on firm investment may change significantly in different institutional environments.

This study makes several contributions to the extant small business management literature. First, it shows that financing sources may influence small business investment. In contrast to the neoclassical 
theory (Modigliani and Miller, 1958), we argue that each financing source has a distinct nature that will use a different mechanism to affect firm investment. In particular, we find that while small firms are inclined to substitute bank-financed capital for profit investment, relationship borrowing will trigger an increase in investment value. This finding provides new evidence that shows that the sources of external finance may exert a significant influence on firm investment decisions. We thus subscribe to Nguyen (2019) and suggest that a lump-sum investigation into the effects of external finance on firm investment cannot yield a meaningful understanding. It is necessary to distinguish the financing sources in an investment equation.

Moreover, this study proposes an alternative perspective to examine the relative importance of formal and informal loans to small businesses. The literature has tried to link formal and informal financing to firm investment but the findings are inconclusive. Beck et al. (2008) suggest that the association of formal and informal finance may change according to a business's stage of development. This strand of theorising, however, provides little assistance to financially constrained small businesses since it holds that firms cannot obtain more external finance until they reach a particular stage of development (e.g., they become big enough in terms of asset size). We suggest that it may be better to conceptualise the association of formal/informal finance and firm investment via the lens of institutional theory. Specifically, the role of external finance on firm investment may change according to the quality and the arrangements of the surrounding institutions. Our findings indicate that when institutional environments improve, small businesses may find it beneficial to increase their use of bank loans and informal loans to boost their investment. The use of external finance may provide entrepreneurs with additional capital to support their investment projects without having to wait until the next stage of development. Thus, perceiving the use of external finance from this perspective, in contrast to the endogenous growth theory (Aghion and Howitt, 1998), highlights the role of the surrounding environments on firm behaviours such as investment, which subsequently affect firm performance and growth.

This study also makes significant contributions to the institutional theory by showing that there is a link between the levels of institutions (see Spigel and Harrison (2018) for a review). Specifically, the lower level of institutions (institutions of governance) may be able to moderate the (negative) effects of the higher level of institutions (entrepreneurship-unfriendly business norms). This finding is important to the literature on small business management for the following reasons. First, it shows that the appropriate unit of institutional analysis should be the surrounding local institutional environments, including the local norms of doing business and the quality of the local government (Nguyen et al., 2018). Small businesses are locally bounded because of their age and size liabilities; 
unlike large companies with nationwide operations, small firms are highly dependent on their local markets, which are strongly shaped by the local norms of doing business and local government quality (Du and Mickiewicz, 2016). Therefore, we propose that it would be more appropriate to investigate small firms' behaviour in the context of their surrounding institutional environments.

In addition, by proposing the significance of local institutions, this study opens a new research strand. It is noteworthy that informal institutions (e.g., business norms in this study) are highly embedded in local values and beliefs (Williamson, 2000). As such, amending and improving them is a lengthy and laborious process (Fritsch and Storey, 2014). Local governance is somewhat more flexible and adjustable in the short and medium terms. More importantly, it can moderate the negative effect of local business norms (e.g., entrepreneurship-unfriendly norms). Therefore, following Nguyen and van Dijk (2012) and Su and Bui (2017), we propose that the role local governance plays in facilitating small business investment is so important that an improved understanding of the minutiae of the mechanisms of local governance arrangements is crucial.

We also argue that a naïve discussion about the relative importance of institutions and external finance cannot yield a meaningful conclusion. In contrast, we find evidence showing that, besides the direct effect, institutions also exert indirect effects on firm investment by influencing the financing decisions of small businesses. Specifically, high-quality local governance may reverse the substitution effect of bank loans. In other words, firms located in well-governed regions have a stronger incentive to invest using both bank loans and retained earnings. This result is particularly meaningful because it demonstrates the overwhelming importance of institutional environments in developing countries. It provides new evidence to reinforce the strand of literature that examines the linkages between local institutions and entrepreneurship (Du and Mickiewicz, 2016; Nguyen, 2019).

The findings of this study have an important implication for policymakers in developing countries. In particular, we suggest that the authorities can facilitate small business investment even where the local norms of doing business are not favourable to entrepreneurship. One way to get around obstructive business norms and successfully boost small firm investment is to improve local governance quality.

Finally, this study is not without limitations that should be acknowledged, but they also provide potential avenues for future research. First, the generalisability of this study may be limited because the sample is restricted to Vietnamese small businesses that are exposed to Vietnamese management styles, possibly hindering the generalisability of the findings. Future studies, therefore, should extend the proposed theoretical framework and re-test it in other contexts. Second, the variable business 
norms in this study are represented by a dummy of North Vietnam and South Vietnam. This is clearly not a perfect measurement of the informal institutional differences among regions. Future study may design questionnaires that capture business norms in a more detailed manner, which would allow a deeper understanding of the impact of informal institutions on firm investment. 
Tables and Figures:

\section{Table 1: Variable Definition and Summary Statistics}

\begin{tabular}{|c|c|c|c|c|c|}
\hline Variable & Definition & Mean & SD & Min & Max \\
\hline Investment & The ratio of firm investment value to total capital & 0.28 & 0.43 & 0.00 & 2.63 \\
\hline $\begin{array}{r}\text { Governance } \\
\text { quality }\end{array}$ & $\begin{array}{l}\text { The PCI score, ranging from } 0 \text { to } 100 \text {. The higher the } \\
\text { score, the better the governance quality of local } \\
\text { governments }\end{array}$ & 60.05 & 4.76 & 36.39 & 77.20 \\
\hline Business norms & $\begin{array}{l}\text { A dummy variable, taking value } 1 \text { for firms located } \\
\text { in South Vietnam, and value } 0 \text { for firms located in } \\
\text { North Vietnam }\end{array}$ & 0.57 & 0.49 & 0 & 1 \\
\hline Bank loans & $\begin{array}{l}\text { The ratio of the value of bank-financed investment } \\
\text { to total capital }\end{array}$ & 0.06 & 0.14 & 0 & 0.92 \\
\hline Informal loans & $\begin{array}{l}\text { The ratio of the value of relationship-financed } \\
\text { investment to total capital }\end{array}$ & 0.02 & 0.07 & 0 & 0.47 \\
\hline Firm size & $\begin{array}{l}\text { Natural log of the number of employees (reported } \\
\text { here as the number of employees) }\end{array}$ & 15.19 & 49.86 & 1 & 299 \\
\hline Firm age & Years of operation since the firm's establishment & 5.61 & 4.37 & 1 & 68 \\
\hline Owner gender & $\begin{array}{l}\text { A dummy variable, taking value } 1 \text { for male and value } \\
0 \text { for female }\end{array}$ & 0.71 & 0.45 & 0 & 1 \\
\hline Owner age & Age of the owner of a business & 41.97 & 9.86 & 24 & 69 \\
\hline Owner education & $\begin{array}{l}\text { A categorical variable, taking value } 1 \text { for doctoral } \\
\text { degrees, } 2 \text { for masters, } 3 \text { bachelors, } 4 \text { college } \\
\text { degrees, } 5 \text { professional vocational degrees, } 6 \text { senior } \\
\text { technical degrees, } 7 \text { junior technical degrees, and } 8 \\
\text { no degree }\end{array}$ & 5.50 & 1.71 & 1 & 8 \\
\hline Distance & $\begin{array}{l}\text { Distance from a province to the closest municipal } \\
\text { city, in } \mathrm{km}\end{array}$ & 90.16 & 123.21 & 1 & 499 \\
\hline $\begin{array}{r}\text { Population } \\
\text { density }\end{array}$ & $\begin{array}{l}\text { The ratio of population over area by province per } \\
\text { year, in person per } \mathrm{km}^{2}\end{array}$ & 1,539 & 1276 & 39 & 3,888 \\
\hline Consumption & $\begin{array}{l}\text { The value of average consumption of a province in } \\
\text { a year depreciated to } 2010 \text { value, in million VND per } \\
\text { capita }\end{array}$ & 31.06 & 21.58 & 1.11 & 89.12 \\
\hline Labour force & $\begin{array}{l}\text { The number of working people over total } \\
\text { population by province per year }\end{array}$ & 0.56 & 0.04 & 0.45 & 0.79 \\
\hline
\end{tabular}

Note: The number of observations is 1,335,157 firm-year in Vietnam in the period 2006-2016. The sample only includes domestic private micro and small and medium-sized enterprises. The governance quality variable is obtained from the Provincial Competitiveness Index (PCI) dataset. The firm-level variables are obtained from the Annual Enterprise Survey dataset of Vietnam General Statistics Office (GSO). The provincial-level variables are obtained from the Annual Statistics Books of Vietnam. 
Table 2: Regression Results: Baseline Specifications

\begin{tabular}{|c|c|c|c|c|c|c|}
\hline \multirow{3}{*}{ Local governance (PCI scores) } & (1) & (2) & (3) & (4) & (5) & (6) \\
\hline & $0.102^{* * *}$ & & $1.035^{* * *}$ & & $0.674 * * *$ & $0.851^{* * *}$ \\
\hline & $(0.024)$ & & $(0.072)$ & & $(0.075)$ & $(0.096)$ \\
\hline \multirow{2}{*}{ Business norms (South dummy) } & & $0.351^{* * *}$ & $49.29^{* * *}$ & & $2.637^{* * *}$ & $36.42^{* * *}$ \\
\hline & & $(0.109)$ & $(7.423)$ & & $(0.523)$ & $(11.760)$ \\
\hline \multirow[t]{2}{*}{ Business norms $\times$ Local governance } & & & $-0.877^{* * *}$ & & & $-0.561^{* * *}$ \\
\hline & & & $(0.123)$ & & & $(0.195)$ \\
\hline \multirow[t]{2}{*}{ Bank loans } & & & & $-41.75^{* * *}$ & $-23.80^{* * *}$ & -11.14 \\
\hline & & & & $(5.730)$ & $(8.109)$ & $(8.797)$ \\
\hline \multirow[t]{2}{*}{ Informal loans } & & & & $101.8^{* * *}$ & $448.0^{* * *}$ & $435.3^{* * *}$ \\
\hline & & & & $(10.070)$ & $(25.370)$ & $(25.210)$ \\
\hline \multirow{2}{*}{ Firm size } & $-9.779 * * *$ & $-10.31^{* * *}$ & $-9.927^{* * *}$ & $-11.16^{* * *}$ & $-5.692^{* * *}$ & $-5.470 * * *$ \\
\hline & $(0.217)$ & $(0.214)$ & $(0.216)$ & $(0.230)$ & $(0.388)$ & $(0.384)$ \\
\hline \multirow[t]{2}{*}{ Firm age } & $-0.260 * * *$ & $-0.238^{* * *}$ & $-0.254^{* * *}$ & $-0.208^{* * *}$ & $-0.249 * * *$ & $-0.250 * * *$ \\
\hline & $(0.014)$ & $(0.014)$ & $(0.014)$ & $(0.015)$ & $(0.018)$ & $(0.018)$ \\
\hline \multirow[t]{2}{*}{ Owner gender dummy } & $-0.862^{* * *}$ & $-0.860^{* * *}$ & $-0.816^{* * *}$ & $-0.813^{* * *}$ & $-0.404^{* * *}$ & $-0.378^{* * *}$ \\
\hline & $(0.104)$ & $(0.104)$ & $(0.104)$ & $(0.108)$ & $(0.132)$ & $(0.130)$ \\
\hline \multirow[t]{2}{*}{ Owner age } & $-0.057^{* * *}$ & $-0.054^{* * *}$ & $-0.055^{* * *}$ & $-0.046^{* * *}$ & $-0.072^{* * *}$ & $-0.074 * * *$ \\
\hline & $(0.006)$ & $(0.006)$ & $(0.006)$ & $(0.006)$ & $(0.007)$ & $(0.007)$ \\
\hline \multirow[t]{2}{*}{ Distance } & $-18.19 * * *$ & $-19.21^{* * *}$ & $-13.08^{* * *}$ & $-14.17^{* * *}$ & $4.617^{* * *}$ & 0.418 \\
\hline & $(0.598)$ & $(0.603)$ & $(1.355)$ & $(0.799)$ & $(1.584)$ & $(2.161)$ \\
\hline \multirow[t]{2}{*}{ Population density } & -1.085 & -1.341 & $1.991^{*}$ & -0.733 & $12.88^{* * *}$ & $15.50 * * *$ \\
\hline & $(0.923)$ & $(0.922)$ & (1.061) & (1.027) & (1.493) & (1.709) \\
\hline \multirow[t]{2}{*}{ Provincial consumption } & $-18.87 * * *$ & $-17.97^{* * *}$ & $-20.26^{* * *}$ & $-17.64^{* * *}$ & $-17.60^{* * *}$ & $-19.09 * * *$ \\
\hline & $(0.804)$ & $(0.819)$ & $(0.954)$ & $(0.881)$ & $(1.137)$ & $(1.270)$ \\
\hline \multirow[t]{2}{*}{ Labour force } & $-29.04^{* * *}$ & $-26.91^{* * *}$ & $-30.63^{* * *}$ & $-18.96^{* * *}$ & $7.913^{* * *}$ & 4.685 \\
\hline & $(1.802)$ & $(1.825)$ & $(2.001)$ & $(2.164)$ & $(2.995)$ & (3.198) \\
\hline $\mathrm{AR}(2)$ & 0.35 & 0.37 & 0.43 & 0.14 & 0.21 & 0.36 \\
\hline Hansen (J) & 0.03 & 0.06 & 0.08 & 0.11 & 0.03 & 0.08 \\
\hline Observations & $1,335,157$ & $1,335,157$ & $1,335,157$ & $1,335,157$ & $1,335,157$ & $1,335,157$ \\
\hline
\end{tabular}

Note: The dependent variable is investment rate. All estimations include full sets of two-digit industry dummies, 11-year dummies, and 8 dummies for owner education. Standard errors and test statistics are asymptotically robust to heteroskedasticity. The estimator is SGMM (xabond2 in Stata). Endogenous variables include the two institutional variables, two external financing variables, and the firm size variable. The instruments for difference equation are the lagged 3- to 4-year level-variables. The instruments for level equation are the lagged 2- to 3-year difference-variables. AR(2) is 
autocorrelation test under the null that there is no autocorrelation in the transformed equations. Hansen (J) is over-identification test, under the null that the overidentifying restrictions are valid, the statistic is asymptotically distributed as a chi-square variable. For display purposes, the unit of investment is percentage times 100 , the unit of population density is people/m2, the unit of distance is hundred km, and the unit of consumption is thousand VND/person. These units are different from the conventional units reported in Table1.

Table 3: Regression Results: Moderation Effects

\begin{tabular}{|c|c|c|c|c|}
\hline & (1) & (2) & (3) & (4) \\
\hline \multirow[t]{2}{*}{ Local governance (PCI scores) } & 0.152 & $0.932^{* * *}$ & $0.531^{* * *}$ & $0.856^{* * *}$ \\
\hline & $(0.129)$ & $(0.101)$ & $(0.155)$ & $(0.104)$ \\
\hline \multirow[t]{2}{*}{ Business norms (South dummy) } & $55.79 * * *$ & $27.49^{* *}$ & $23.52^{*}$ & -0.361 \\
\hline & (11.79) & (12.55) & $(13.06)$ & (14.09) \\
\hline \multirow[t]{2}{*}{ Business norms $\times$ Local governance } & $-0.878^{* * *}$ & $-0.569 * * *$ & -0.341 & -0.100 \\
\hline & $(0.195)$ & $(0.207)$ & $(0.217)$ & $(0.227)$ \\
\hline \multirow[t]{2}{*}{ Bank loans } & $-680.4^{* * *}$ & $-112.8^{* * *}$ & $-24.33^{* *}$ & $-22.30^{* *}$ \\
\hline & $(82.63)$ & $(15.45)$ & $(10.49)$ & $(10.17)$ \\
\hline \multirow[t]{2}{*}{ Informal loans } & $399.3^{* * *}$ & $431.9^{* * *}$ & -136.9 & $294.0^{* * *}$ \\
\hline & $(25.00)$ & $(26.01)$ & $(220.6)$ & $(32.69)$ \\
\hline \multirow[t]{2}{*}{ Local governance $\times$ Bank loans } & $10.90^{* * *}$ & & & \\
\hline & $(1.332)$ & & & \\
\hline \multirow[t]{2}{*}{ Business norms $\times$ Bank loans } & & $152.6^{* * *}$ & & \\
\hline & & $(17.72)$ & & \\
\hline \multirow[t]{2}{*}{ Local governance $\times$ Informal loans } & & & $10.17^{* * *}$ & \\
\hline & & & $(3.924)$ & \\
\hline \multirow[t]{2}{*}{ Business norms $\times$ Informal loans } & & & & $420.0^{* * *}$ \\
\hline & & & & $(52.64)$ \\
\hline \multirow[t]{2}{*}{ Firm size } & $-6.347^{* * *}$ & $-6.193^{* * *}$ & $-5.597 * * *$ & $-5.899 * * *$ \\
\hline & $(0.400)$ & $(0.414)$ & $(0.406)$ & $(0.431)$ \\
\hline \multirow[t]{2}{*}{ Firm age } & $-0.266^{* * *}$ & $-0.267^{* * *}$ & $-0.253^{* * *}$ & $-0.228^{* * *}$ \\
\hline & $(0.018)$ & $(0.018)$ & $(0.019)$ & $(0.020)$ \\
\hline \multirow[t]{2}{*}{ Owner gender dummy } & $-0.345^{* * *}$ & $-0.224^{*}$ & $-0.395^{* * *}$ & $-0.429^{* * *}$ \\
\hline & $(0.129)$ & $(0.136)$ & $(0.134)$ & $(0.144)$ \\
\hline \multirow[t]{2}{*}{ Owner age } & $-0.0665^{* * *}$ & $-0.0648^{* * *}$ & $-0.0737^{* * *}$ & $-0.0763^{* * *}$ \\
\hline & $(0.007)$ & $(0.007)$ & $(0.007)$ & $(0.008)$ \\
\hline Distance & $-4.210^{*}$ & 0.502 & 2.560 & $6.666^{* * *}$ \\
\hline
\end{tabular}




\begin{tabular}{rllll}
\hline & $(2.234)$ & $(2.239)$ & $(2.373)$ & $(2.568)$ \\
Population density & $19.78^{* * *}$ & $26.52^{* * *}$ & $16.55^{* * *}$ & $18.34^{* * *}$ \\
& $(1.760)$ & $(2.156)$ & $(1.842)$ & $(1.864)$ \\
Provincial consumption & $-26.15^{* * *}$ & $-27.21^{* * *}$ & $-19.28^{* * *}$ & $-15.87^{* * *}$ \\
& $(1.550)$ & $(1.630)$ & $(1.314)$ & $(1.417)$ \\
Labour force & -5.168 & 3.765 & $5.914^{*}$ & $13.76^{* * *}$ \\
& $(3.407)$ & $(3.322)$ & $(3.373)$ & $(3.883)$ \\
AR(2) & 0.36 & 0.35 & 0.35 & 0.33 \\
Hansen (J) & 0.09 & 0.08 & 0.09 & 0.09 \\
Observations & $1,335,157$ & $1,335,157$ & $1,335,157$ & $1,335,157$ \\
\hline
\end{tabular}

Note: The dependent variable is investment rate. All estimations include full sets of two-digit industry dummies, 11-year dummies, and 8 dummies for owner education. Standard errors and test statistics are asymptotically robust to heteroskedasticity. The estimator is SGMM (xabond2 in Stata). Endogenous variables include the two institutional variables, two external financing variables, and the firm size variable. The instruments for difference equation are the lagged 3- to 4-year level-variables. The instruments for level equation are the lagged 2- to 3-year difference-variables. AR(2) is autocorrelation test under the null that there is no autocorrelation in the transformed equations. Hansen (J) is over-identification test, under the null that the overidentifying restrictions are valid, the statistic is asymptotically distributed as a chi-square variable. For display purposes, the unit of investment is percentage times 100 , the unit of population density is people $/ \mathrm{m} 2$, the unit of distance is hundred $\mathrm{km}$, and the unit of consumption is thousand VND/person. These units are different from the conventional units reported in Table1.

\section{Figure 1: The Moderation of Institutions on External Finance}

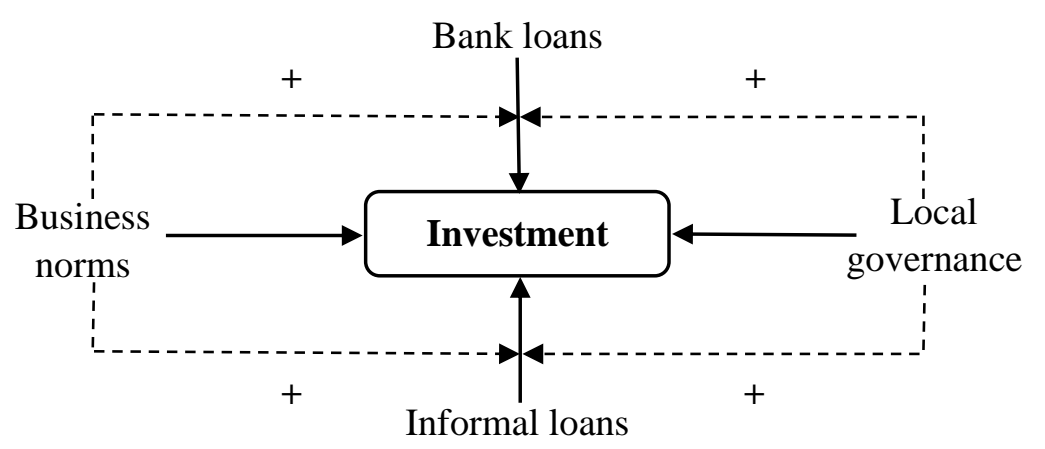




\section{Figure 2: Margin of Business Norms on Bank Loans}

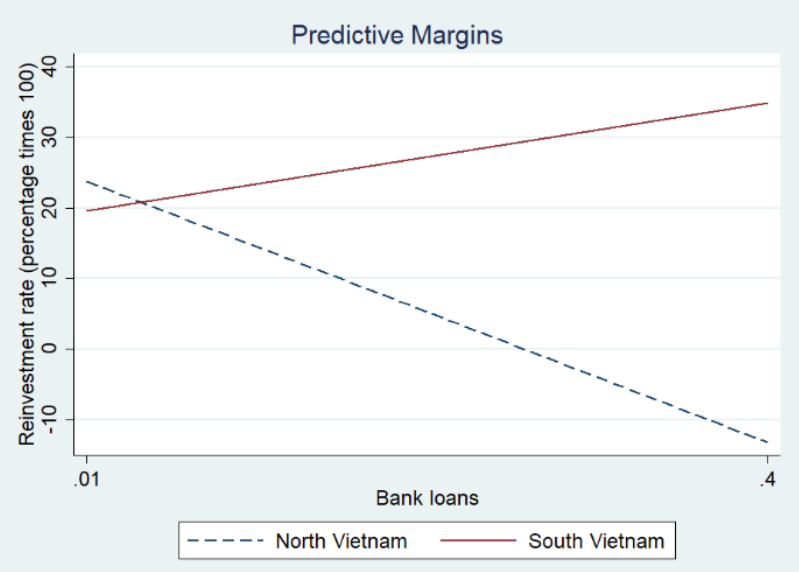

Figure 3: Margin of Business Norms on Informal Loans

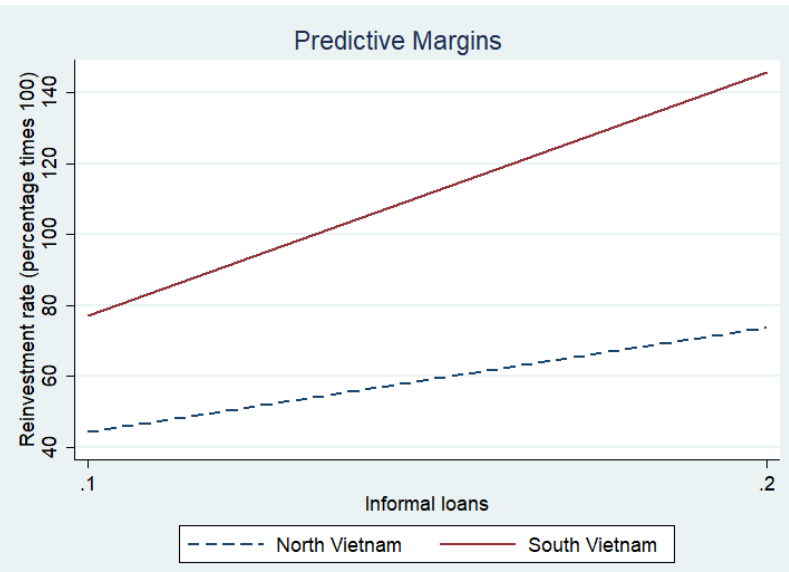

Figure 4: Margin of Local Governance Quality on Bank Loans

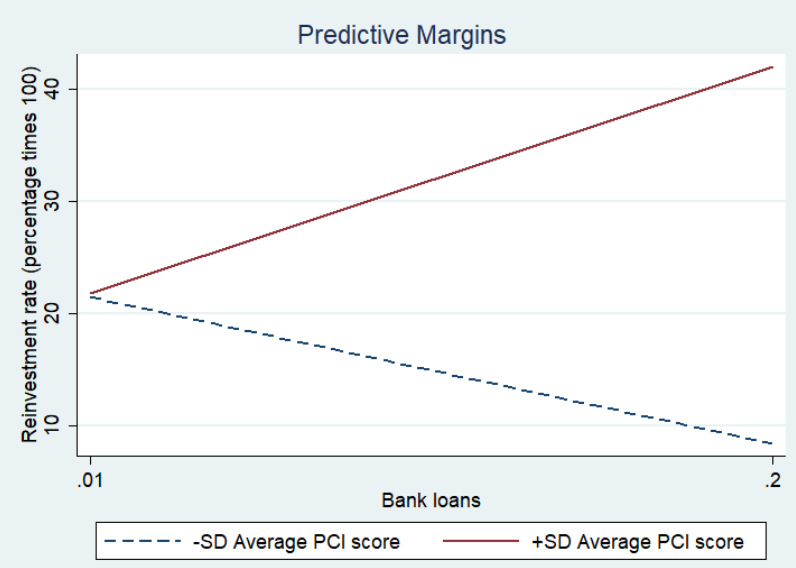

Figure 5: Margin of Local Governance Quality on Informal Loans

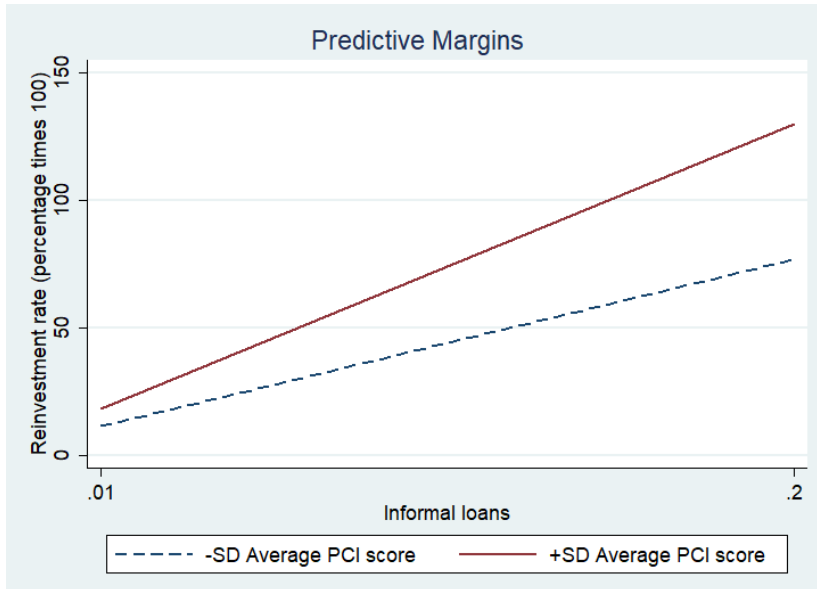




\section{References:}

Acemoglu, D. and Johnson, S. (2005), 'Unbundling Institutions', Journal of Political Economy, 113(5): 949-995. Adomdza, G., Åstebro, T. and Yong, K. (2016), 'Decision biases and entrepreneurial finance', Small Business Economics, 47(4): 819-834.

Aghion, P. and Howitt, P. (1998). Endogenous growth theory: Cambridge, MA : MIT Press.

Ahunov, M. and Yusupov, N. (2017), 'Risk Attitudes and Entrepreneurial Motivations: Evidence from Transition Economies', Economics Letters, 160(11): 7-11.

Aldrich, R. (2014), 'Imperial Banishment: French Colonizers and the Exile of Vietnamese Emperors', French History \& Civilization, 5(1): 123-133.

Allen, F., Jun, Q. and Meijun, Q. (2005), 'Law, finance, and economic growth in China', Journal of Financial Economics, 77(1): 57-116.

Ayyagari, M., Demirgüç-Kunt, A. and Maksimovic, V. (2010), 'Formal versus Informal Finance: Evidence from China', Review of Financial Studies, 23(8): 3048-3097.

Baron, R. A. (2007), 'Behavioral and cognitive factors in entrepreneurship: entrepreneurs as the active element in new venture creation', Strategic Entrepreneurship Journal, 1(1-2): 167-182.

Barton, S. L. and Gordon, P. J. (1987), 'Corporate Strategy: Useful Perspective for the Study of Capital Structure?', Academy of Management Review, 12(1): 67-75.

Baumol, W. J. S. R. J. (2007), 'Entrepreneurship and economic growth', SEJ Strategic Entrepreneurship Journal, 1(3-4): 233-237.

Beck, T., Demirgüç-Kunt, A. and Maksimovic, V. (2008), 'Financing patterns around the world: Are small firms different?', Journal of Financial Economics, 89(3): 467-487.

Beck, T., Lu, L. and Yang, R. (2015), 'Finance and Growth for Microenterprises: Evidence from Rural China', World Development, 67(3): 38-56.

Bertrand, M. and Schoar, A. (2006), 'The Role of Family in Family Firms', Journal of Economic Perspectives, 20(2): 73-96.

Bruton, G. D., Ahlstrom, D. and Li, H. L. (2010), 'Institutional theory and entrepreneurship: Where are we now and where do we need to move in the future?', Entrepreneurship: Theory and Practice, 34(3): 421-440.

Busenitz, L. W., Gómez, C. and Spencer, J. W. (2000), 'Country Institutional Profiles: Unlocking Entrepreneurial Phenomena', Academy of Management Journal, 43(5): 994-1003.

Canh Phuc, N., Christophe, S., Thanh Dinh, S. and Felicia, C. (2018), 'Institutions, inward foreign direct investment, trade openness and credit level in emerging market economies', Review of Development Finance, 8(2): 75-88.

Carpenter, R. E. and Petersen, B. C. (2002), 'Is The Growth of Small Firms Constrained by Internal Finance?', Review of Economics \& Statistics, 84(2): 298-309.

Carreira, C. and Silva, F. (2010), 'No Deep Pockets: Some Stylized Empirical Results on Firms' Financial Constraints', Journal of Economic Surveys, 24(4): 731-753.

Chien, N. D. and Kezhong, Z. (2012), 'FDI of Vietnam; Two-Way Linkages between FDI and GDP, Competition among Provinces and Effects of Laws', I-Business, 4(2): 157-163.

Chua, J. H., Chrisman, J. J., Kellermanns, F. and Wu, Z. (2011), 'Family involvement and new venture debt financing', Journal of business venturing, 26(4): 472-488.

Cressy, R. and Olofsson, C. (1997), 'The Financial Conditions for Swedish SMEs: Survey and Research Agenda', Small Business Economics, 9(2): 179-194.

Cull, R. and Xu, L. C. (2005), 'Institutions, Ownership, and Finance: The Determinants of Profit Reinvestment among Chinese Firms', Journal of Financial Economics, 77(1): 117-146.

Cumming, D. and Johan, S. (2017), 'The Problems with and Promise of Entrepreneurial Finance', Strategic Entrepreneurship Journal, 11(3): 357-370.

De Castro, J. O., Khavul, S. and Bruton, G. D. (2014), 'Shades of Grey: How do Informal Firms Navigate Between Macro and Meso Institutional Environments?', Strategic Entrepreneurship Journal, 8(1): 75-94. 
Dell, M., Lane, N. and Querubin, P. (2018), 'The Historical State, Local Collective Action, and Economic Development in Vietnam', Econometrica, 86(6): 2083-2122.

Du, J., Guariglia, A. and Newman, A. (2015), 'Do Social Capital Building Strategies Influence the Financing Behavior of Chinese Private Small and Medium-Sized Enterprises?', Entrepreneurship: Theory \& Practice, 39(3): 601-631.

Du, J. and Mickiewicz, T. (2016), 'Subsidies, rent seeking and performance: Being young, small or private in China', Journal of business venturing, 31(1): 22-38.

Efendic, A., Mickiewicz, T. and Rebmann, A. (2015), 'Growth aspirations and social capital: Young firms in a post-conflict environment', International Small Business Journal, 33(5): 537-561.

Fraser, S., Bhaumik, S. K. and Wright, M. (2015), 'What do we know about entrepreneurial finance and its relationship with growth?', International Small Business Journal, 33(1): 70-88.

Fritsch, M. and Storey, D. J. (2014), 'Entrepreneurship in a Regional Context: Historical Roots, Recent Developments and Future Challenges', Regional Studies, 48(6): 939-954.

Gartner, W. B., Frid, C. J. and Alexander, J. C. (2012), 'Financing the Emerging Firm', Small Business Economics, 39(3): 745-761.

Guariglia, A. and Liu, P. (2014), 'To What Extent Do Financing Constraints Affect Chinese Firms' Innovation Activities?', International Review of Financial Analysis, 36(12): 223-240.

Hartwell, C. (2017), 'The Coevolution of Finance and Property Rights: Evidence from Transition Economies', Journal of Economic Issues (Taylor \& Francis Ltd), 51(1): 73-97.

Holmberg, S., Rothstein, B. and Nasiritousi, N. (2009), 'Quality of Government: What You Get', Annual Review of Political Science, 12(6): 135-161.

Jiang, W. and Zeng, Y. (2014), 'State ownership, bank loans, and corporate investment', International Review of Economics \& Finance, 32(7): 92-116.

Johnson, S., McMillan, J. and Woodruff, C. (2002), 'Property Rights and Finance', American Economic Review, 92(5): 1335-1356.

Karaivanov, A. and Kessler, A. (2018), '(Dis)advantages of informal loans - Theory and evidence', European Economic Review, 102(2): 100-128.

Lainez, N. (2014), 'Informal Credit in Vietnam: A Necessity Rather Than an Evil', Journal of Southeast Asian Economies, 31(1): 147-154.

Le, P. T., Harvie, C., Arjomandi, A. and Borthwick, J. (2019), 'Financial liberalisation, bank ownership type and performance in a transition economy: The case of Vietnam', Pacific-Basin Finance Journal, 57(Oct): 101182.

Lee, S. and Persson, P. (2016), 'Financing from Family and Friends', Review of Financial Studies, 29(9): 23412386.

Makino, S. and Tsang, E. W. K. (2011), 'Historical Ties and Foreign Direct Investment: An Exploratory Study', Journal of International Business Studies, 42(4): 545-557.

Malesky, E., McCulloch, N. and Nhat, N. D. (2015), 'The impact of governance and transparency on firm investment in Vietnam', Economics of Transition, 23(4): 677-715.

Marcelin, I. and Mathur, I. (2014), 'Financial development, institutions and banks', International Review of Financial Analysis, 31(1): 25-33.

McMillan, J. and Woodruff, C. (2002), 'The Central Role of Entrepreneurs in Transition Economies', Journal of Economic Perspectives, 16(3): 153-170.

Modigliani, F. and Miller, M. H. (1958), 'The Cost of Capital, Corporation Finance and the Theory of Investment', American Economic Review, 48(3): 261-297.

Myers, S. C. (1984), 'The Capital Structure Puzzle', Journal of Finance, 39(3): 575-592.

Nguyen, B. (2019), 'Entrepreneurial Reinvestment: Local Governance, Ownership, and Financing Matter Evidence from Vietnam', Journal of Small Business Management, 57(2): 323-349.

Nguyen, B. (2019), 'Local Institutions on Small Firm Investments: Degrees of Institutional Persistence Matter', International Journal of Entrepreneurship and Small Business, In Press. 
Nguyen, B., Mickiewicz, T. and Du, J. (2018), 'Local governance and business performance in Vietnam: the transaction costs perspective', Regional Studies, 52(4): 542-557.

Nguyen, C. V. and van den Berg, M. (2014), 'Informal Credit, Usury, or Support? A Case Study for Vietnam', Developing Economies, 52(2): 154-178.

Nguyen, T. P. T., Nghiem, S. H., Roca, E. and Sharma, P. (2016), 'Bank reforms and efficiency in Vietnamese banks: evidence based on SFA and DEA', Applied Economics, 48(30): 2822-2835.

Nguyen, T. T. and van Dijk, M. A. (2012), 'Corruption, Growth, and Governance: Private vs. State-Owned Firms in Vietnam', Journal of Banking and Finance, 36(11): 2935-2948.

Nguyen, T. V., Le, N. T. B. and Freeman, N. J. (2006), 'Trust and Uncertainty: A Study of Bank Lending to Private SMEs in Vietnam', Asia Pacific Business Review, 12(4): 547-568.

North, D. C. (1990). Institutions, institutional change and economic performance / Douglass C. North: Cambridge : Cambridge University Press.

O'Toole, C. M., Morgenroth, E. L. W. and Ha, T. T. (2016), 'Investment efficiency, state-owned enterprises and privatisation: Evidence from Viet Nam in Transition', Journal of Corporate Finance, 37(4): 93-108.

Pham, T. and Talavera, O. (2018), 'Discrimination, Social Capital, and Financial Constraints: The Case of Viet Nam', World Development, 102(2): 228-242.

Phuc Canh, N., Schinckus, C. and Thanh, S. D. (2019), 'Do economic openness and institutional quality influence patents? Evidence from GMM systems estimates', International Economics, 157(5): 134-169.

Sarah, T. and Phuong An, N. (2005), 'Young Entrepreneurs, Social Capital and "Doi Moi" in Hanoi, Vietnam', Urban Studies, 42(10): 1693-1710.

Shultz, C. J., Speece, M. W. and Pecotich, A. (2000), 'The Evolving Investment Climate in Vietnam and Subsequent Challenges to Foreign Investors', Thunderbird International Business Review, 42 (6): 735753.

Spigel, B. and Harrison, R. (2018), 'Toward a process theory of entrepreneurial ecosystems', Strategic Entrepreneurship Journal, 12(1): 151-168.

Stephan, U., Uhlaner, L. M. and Stride, C. (2015), 'Institutions and social entrepreneurship: the role of institutional voids, institutional support, and institutional configurations', Journal of International Business Studies, 46(3): 308-331.

Su, D. T., Nguyen, P. C. and Schinckus, C. (2019), 'Impact of Foreign Direct Investment, Trade Openness and Economic Institutions on Growth in Emerging Countries: The Case of Vietnam', Journal of International Studies, 12(3): 243-264.

$\mathrm{Su}$, T. D. and Bui, T. M. H. (2017), 'Government size, public governance and private investment: The case of Vietnamese provinces', Economic systems, 41(4): 651-666.

Tran, H. T. and Santarelli, E. (2014), 'Capital Constraints and the Performance of Entrepreneurial Firms in Vietnam', Industrial and Corporate Change, 23(3): 827-864.

Vanacker, T. R. and Manigart, S. (2010), 'Pecking Order and Debt Capacity Considerations for High-Growth Companies Seeking Financing', Small Business Economics, 35(1): 53-69.

Williamson, O. E. (1985). The economic institutions of capitalism : firms, markets, relational contracting. New York; London: Free Press ; Collier Macmillan.

Williamson, O. E. (2000), 'The New Institutional Economics: Taking Stock, Looking Ahead', Journal of Economic Literature, 38(3): 595-613.

Wu, J., Si, S. and Wu, X. (2016), 'Entrepreneurial Finance and Innovation: Informal Debt as an Empirical Case', Strategic Entrepreneurship Journal, 10(3): 257-273.

Zhou, W. (2013), 'Political connections and entrepreneurial investment: Evidence from China's transition economy', Journal of business venturing, 28(2): 299-315.

Zhou, W. (2017), 'Institutional environment, public-private hybrid forms, and entrepreneurial reinvestment in a transition economy', Journal of business venturing, 32(2): 197-214. 
Appendix 1: Details of Panel Structure

\begin{tabular}{|c|c|c|c|}
\hline Year & Frequency & Percentage & $\begin{array}{l}\text { Cumulative } \\
\text { percentage }\end{array}$ \\
\hline 2006 & 82,231 & $6.16 \%$ & $6.16 \%$ \\
\hline 2007 & 102,765 & $7.70 \%$ & $13.86 \%$ \\
\hline 2008 & 137,823 & $10.32 \%$ & $24.18 \%$ \\
\hline 2009 & 43,081 & $3.23 \%$ & $27.41 \%$ \\
\hline 2010 & 215,409 & $16.13 \%$ & $43.54 \%$ \\
\hline 2011 & 145,720 & $10.91 \%$ & $54.45 \%$ \\
\hline 2012 & 265,989 & $19.92 \%$ & $74.37 \%$ \\
\hline 2013 & 81,017 & $6.07 \%$ & $80.44 \%$ \\
\hline 2014 & 50,890 & $3.81 \%$ & $84.25 \%$ \\
\hline 2015 & 191,512 & $14.34 \%$ & $98.60 \%$ \\
\hline 2016 & 18,720 & $1.40 \%$ & $100.00 \%$ \\
\hline Total & $1,335,157$ & $100 \%$ & \\
\hline $\begin{array}{c}\text { Number of year per } \\
\text { firm }\end{array}$ & Frequency & Percentage & $\begin{array}{l}\text { Cumulative } \\
\text { percentage }\end{array}$ \\
\hline 1 & 295,558 & $22.14 \%$ & $22.14 \%$ \\
\hline 2 & 363,203 & $27.20 \%$ & $49.34 \%$ \\
\hline 3 & 250,299 & $18.75 \%$ & $68.09 \%$ \\
\hline 4 & 171,416 & $12.84 \%$ & $80.93 \%$ \\
\hline 5 & 132,605 & $9.93 \%$ & $90.86 \%$ \\
\hline 6 & 78,450 & $5.88 \%$ & $96.73 \%$ \\
\hline 7 & 32,242 & $2.41 \%$ & $99.15 \%$ \\
\hline 8 & 6,632 & $0.50 \%$ & $99.64 \%$ \\
\hline 9 & 1,152 & $0.09 \%$ & $99.73 \%$ \\
\hline 10 & 2,500 & $0.19 \%$ & $99.92 \%$ \\
\hline 11 & 1,100 & $0.08 \%$ & $100.00 \%$ \\
\hline Total & $1,335,157$ & $100 \%$ & \\
\hline
\end{tabular}

\section{Appendix 2: PCI Sub-indices}

\section{Variable}

Legal

institutions

\section{Definition}

Measures the confidence in provincial legal institutions; whether firms regard provincial legal institutions as an effective vehicle for dispute resolution, or as an avenue for lodging appeals against corrupt official behaviours. The indicator is two-digit value, ranging from 1 to 10 , the higher the score, the better the institutions.

Entry costs Measures the differences in entry costs for new firms across provinces (for example, length of business registration in days, etc.). The indicator is twodigit value, ranging from 1 to 10 , the higher the score, the lower the entry costs.

Combines two dimensions of the land problems confronting entrepreneurs: how easy it is to access land and the security of tenure once land is acquired. The variable is two-digit value, ranging from 1 to 10 , the higher the score, the better the access.

\begin{tabular}{cccc} 
Mean & S.D. & Min. & Max. \\
& & & \\
4.58 & 1.05 & 2.00 & 7.91 \\
& & & \\
7.73 & 0.98 & 4.96 & 9.60 \\
& & & \\
5.05 & 1.51 & 1.94 & 8.84 \\
\hline
\end{tabular}




\begin{tabular}{|c|c|c|c|c|c|}
\hline Time costs & $\begin{array}{l}\text { Measures how much time firms waste on bureaucratic compliance, as well } \\
\text { as how often and for how long firms must shut down their operations for } \\
\text { inspections by local regulatory agencies. The indicator is two-digit value, } \\
\text { ranging from } 1 \text { to } 10 \text {, the higher the score, the better the access. }\end{array}$ & 5.84 & 0.81 & 2.64 & 8.93 \\
\hline $\begin{array}{l}\text { Business } \\
\text { supports }\end{array}$ & $\begin{array}{l}\text { Measures provincial services for trade promotion, provision of regulatory } \\
\text { information to firms, business partner matchmaking, provision of } \\
\text { industrial zones or industrial clusters, and technological services for firms. } \\
\text { The indicator is two-digit value, ranging from } 1 \text { to } 10 \text {, the higher the score, } \\
\text { the better the support. }\end{array}$ & 6.05 & 1.53 & 1.40 & 9.62 \\
\hline Labour training & $\begin{array}{l}\text { Measures the efforts by provincial authorities to promote vocational } \\
\text { training and skills development for local industries and to assist in the } \\
\text { placement of local labour. The indicator is two-digit value, ranging from } 1 \\
\text { to } 10 \text {, the higher the score, the better the training. }\end{array}$ & 5.92 & 0.99 & 1.84 & 9.60 \\
\hline $\begin{array}{r}\text { Informal } \\
\text { Charge }\end{array}$ & $\begin{array}{l}\text { Measures how much firms pay in informal charges, how much of an } \\
\text { obstacle those extra fees pose for their business operations, whether } \\
\text { payment of those extra fees results in the expected results or "services," } \\
\text { and whether provincial officials use compliance with local regulations to } \\
\text { extract rents. The indicator is two-digit value, ranging from } 1 \text { to } 10 \text {, the } \\
\text { higher the score, the lower the charges (corruption). }\end{array}$ & 5.90 & 0.99 & 4.13 & 8.94 \\
\hline Transparency & $\begin{array}{l}\text { Measures whether firms have access to the proper planning and legal } \\
\text { documents necessary to run their businesses, whether those documents } \\
\text { are equitably available, new policies and laws are communicated to firms } \\
\text { and predictably implemented. The indicator is two-digit value, ranging } \\
\text { from } 1 \text { to } 10 \text {, the higher the score, the more transparent. }\end{array}$ & 5.62 & 1.47 & 2.14 & 8.56 \\
\hline $\begin{array}{l}\text { Leadership } \\
\text { proactivity }\end{array}$ & $\begin{array}{l}\text { Measures the creativity and cleverness of provinces in implementing } \\
\text { central policy, designing their own initiatives for private sector } \\
\text { development, and working within sometimes unclear national regulatory } \\
\text { frameworks to assist and interpret in favour of local private firms. The } \\
\text { indicator is two-digit value, ranging from } 1 \text { to } 10 \text {, the higher the score, the } \\
\text { more proactive. }\end{array}$ & 4.56 & 1.30 & 1.39 & 9.39 \\
\hline
\end{tabular}

Note: Studying panel encompasses all of 63 provinces and municipal cities in Vietnam in the period 2006-2016, obtained from the Provincial Competitiveness Index (PCI) dataset.

\section{Appendix 3: Correlation Matrix}

\begin{tabular}{|c|c|c|c|c|c|c|c|c|c|c|c|c|}
\hline Investment (1) & (1) & (2) & (3) & (4) & (5) & (6) & (7) & (8) & (9) & $(10)$ & (11) & (12) (13) \\
\hline nance quality (2) & 0.02 & & & & & & & & & & & \\
\hline siness norms (3) & 0.00 & 0.42 & & & & & & & & & & \\
\hline Bank loans (4) & -0.06 & 0.03 & -0.07 & & & & & & & & & \\
\hline formal loans (5) & 0.02 & 0.01 & -0.06 & 0.43 & & & & & & & & \\
\hline Firm size (6) & -0.33 & -0.06 & -0.12 & -0.10 & -0.15 & & & & & & & \\
\hline Firm age (7) & -0.20 & -0.03 & -0.03 & -0.02 & -0.09 & 0.25 & & & & & & \\
\hline wner gender (8) & -0.01 & -0.04 & -0.05 & 0.00 & -0.01 & 0.05 & -0.01 & & & & & \\
\hline Owner age (9) & -0.12 & -0.07 & -0.02 & -0.03 & -0.08 & 0.18 & 0.39 & 0.02 & & & & \\
\hline Distance (10) & -0.06 & -0.35 & -0.03 & -0.13 & -0.26 & 0.10 & 0.09 & 0.05 & 0.15 & & & \\
\hline Density (11) & 0.02 & 0.36 & 0.31 & 0.12 & 0.20 & -0.18 & -0.08 & -0.05 & -0.15 & -0.67 & & \\
\hline onsumption (12) & -0.06 & 0.27 & 0.19 & 0.12 & 0.06 & -0.19 & 0.03 & -0.04 & -0.10 & -0.51 & 0.63 & \\
\hline abour force (13) & -0.07 & -0.07 & -0.17 & -0.07 & -0.14 & 0.09 & 0.12 & 0.02 & 0.06 & 0.34 & -0.24 & 0.12 \\
\hline
\end{tabular}

Note: All correlation coefficients are significant at $1 \%$. 
Appendix 4: Firms with Positive and Negative Profits

\begin{tabular}{|c|c|c|c|c|c|c|c|c|}
\hline & $\begin{array}{c}\text { (1) } \\
\text { Negative } \\
\text { Profits }\end{array}$ & $\begin{array}{c}\text { (2) } \\
\text { Negative } \\
\text { Profits }\end{array}$ & $\begin{array}{c}\text { (3) } \\
\text { Negative } \\
\text { Profits }\end{array}$ & $\begin{array}{c}\text { (4) } \\
\text { Negative } \\
\text { Profits }\end{array}$ & $\begin{array}{c}\text { (5) } \\
\text { Positive } \\
\text { Profits }\end{array}$ & $\begin{array}{c}\text { (6) } \\
\text { Positive } \\
\text { Profits }\end{array}$ & $\begin{array}{c}\text { (7) } \\
\text { Positive } \\
\text { Profits }\end{array}$ & $\begin{array}{c}\text { (8) } \\
\text { Positive } \\
\text { Profits }\end{array}$ \\
\hline \multirow[t]{2}{*}{ Local governance (PCI scores) } & $-0.531^{* *}$ & $1.799^{* * *}$ & $0.553^{* *}$ & $1.225^{* * *}$ & $-0.261^{*}$ & $0.454^{* * *}$ & $-0.524^{* * *}$ & $0.445^{* * *}$ \\
\hline & $(0.270)$ & $(0.170)$ & $(0.261)$ & $(0.145)$ & $(0.149)$ & $(0.126)$ & $(0.114)$ & $(0.128)$ \\
\hline \multirow[t]{2}{*}{ Business norms (South dummy) } & 38.57 & -18.07 & -17.85 & -16.91 & $66.66^{* * *}$ & $46.72^{* * *}$ & 3.702 & $26.52^{* *}$ \\
\hline & $(24.21)$ & $(27.35)$ & $(25.86)$ & $(24.84)$ & $(12.09)$ & $(11.88)$ & $(9.839)$ & $(13.25)$ \\
\hline \multirow[t]{2}{*}{ Business norms $\times$ Local governance } & $-0.648^{*}$ & -0.0724 & 0.237 & 0.103 & $-1.030^{* * *}$ & $-0.779^{* * *}$ & 0.0208 & $-0.435^{* *}$ \\
\hline & $(0.392)$ & $(0.437)$ & $(0.422)$ & $(0.394)$ & $(0.203)$ & $(0.201)$ & $(0.165)$ & $(0.215)$ \\
\hline \multirow[t]{2}{*}{ Bank loans } & $-1,263^{* * *}$ & $-185.7^{* * *}$ & $-49.10^{* * *}$ & $-33.92^{* *}$ & $-824.7^{* * *}$ & $-27.73^{*}$ & $33.65^{* * *}$ & $31.59^{* * *}$ \\
\hline & $(146.5)$ & $(25.45)$ & $(16.80)$ & $(15.85)$ & $(111.8)$ & $(16.16)$ & $(8.050)$ & $(9.300)$ \\
\hline \multirow[t]{2}{*}{ Informal loans } & $283.3^{* * *}$ & $270.8^{* * *}$ & $-1,026^{* * *}$ & $165.7^{* * *}$ & $314.2^{* * *}$ & $338.0^{* * *}$ & -102.4 & $263.1^{* * *}$ \\
\hline & $(57.96)$ & $(56.71)$ & $(383.8)$ & $(58.01)$ & $(23.02)$ & $(23.09)$ & $(166.6)$ & $(28.19)$ \\
\hline \multirow[t]{2}{*}{ Local governance $\times$ Bank loans } & $19.79^{* * *}$ & & & & $14.09^{* * *}$ & & & \\
\hline & $(2.331)$ & & & & $(1.818)$ & & & \\
\hline \multirow[t]{2}{*}{ Business norms $\times$ Bank loans } & & $232.6^{* * *}$ & & & & $96.26^{* * *}$ & & \\
\hline & & $(28.43)$ & & & & $(19.19)$ & & \\
\hline \multirow[t]{2}{*}{ Local governance $\times$ Informal loans } & & & $22.58^{* * *}$ & & & & $5.949^{* *}$ & \\
\hline & & & $(6.682)$ & & & & $(2.989)$ & \\
\hline \multirow[t]{2}{*}{ Business norms $\times$ Informal loans } & & & & $353.5^{* * *}$ & & & & $193.2^{* * *}$ \\
\hline & & & & $(87.63)$ & & & & $(50.42)$ \\
\hline \multirow[t]{2}{*}{ Firm size } & $-11.25^{* * *}$ & $-11.13^{* * *}$ & $-10.41^{* * *}$ & $-10.09 * * *$ & $-4.842^{* * *}$ & $-4.608^{* * *}$ & $-9.701^{* * *}$ & $-4.889 * * *$ \\
\hline & $(0.780)$ & $(0.784)$ & $(0.717)$ & $(0.697)$ & $(0.446)$ & $(0.448)$ & $(0.316)$ & $(0.457)$ \\
\hline \multirow[t]{2}{*}{ Firm age } & $-0.395^{* * *}$ & $-0.408^{* * *}$ & $-0.348^{* * *}$ & $-0.318^{* * *}$ & $-0.169^{* * *}$ & $-0.159 * * *$ & 0.0129 & $-0.131^{* * *}$ \\
\hline & $(0.0341)$ & $(0.0342)$ & $(0.0316)$ & $(0.0326)$ & $(0.0196)$ & $(0.0197)$ & $(0.0158)$ & $(0.0198)$ \\
\hline \multirow[t]{2}{*}{ Owner gender dummy } & $-0.760^{* * *}$ & $-0.738^{* * *}$ & $-1.079 * * *$ & $-1.099 * * *$ & -0.0353 & 0.0605 & -0.0491 & -0.0175 \\
\hline & $(0.213)$ & $(0.211)$ & $(0.198)$ & (0.199) & $(0.148)$ & $(0.150)$ & $(0.135)$ & $(0.152)$ \\
\hline \multirow[t]{2}{*}{ Owner age } & $-0.0363^{* * *}$ & $-0.0336^{* * *}$ & $-0.0563^{* * *}$ & $-0.0668^{* * *}$ & $-0.0528^{* * *}$ & $-0.0545^{* * *}$ & $-0.0289^{* * *}$ & $-0.0541^{* * *}$ \\
\hline & $(0.0124)$ & $(0.0125)$ & $(0.0112)$ & $(0.0113)$ & $(0.00785)$ & $(0.00791)$ & $(0.00711)$ & $(0.00798)$ \\
\hline \multirow[t]{2}{*}{ Distance } & -1.509 & 4.972 & 5.265 & 6.332 & $-4.733^{* *}$ & -1.911 & $-12.29 * * *$ & 0.744 \\
\hline & $(6.258)$ & $(6.471)$ & $(6.119)$ & $(6.144)$ & (1.928) & $(1.894)$ & $(1.421)$ & $(2.153)$ \\
\hline \multirow[t]{2}{*}{ Population density } & $9.497 * * *$ & $22.51^{* * *}$ & 0.706 & 2.961 & $30.44^{* * *}$ & $31.85^{* * *}$ & $18.51^{* * *}$ & $26.36^{* * *}$ \\
\hline & $(3.263)$ & $(3.990)$ & $(2.953)$ & $(3.033)$ & $(2.034)$ & $(2.333)$ & $(1.598)$ & $(1.971)$ \\
\hline
\end{tabular}




\begin{tabular}{rcccccccc}
\hline Provincial consumption & $-34.01^{* * *}$ & $-34.63^{* * *}$ & $-16.61^{* * *}$ & $-14.52^{* * *}$ & $-23.67^{* * *}$ & $-21.98^{* * *}$ & $-17.60^{* * *}$ & $-16.60^{* * *}$ \\
& $(3.127)$ & $(3.170)$ & $(2.565)$ & $(2.689)$ & $(1.515)$ & $(1.569)$ & $(1.130)$ & $(1.320)$ \\
Labour force & -6.844 & $15.57^{*}$ & $23.90^{* * *}$ & $27.76^{* * *}$ & $-5.407^{*}$ & -0.242 & $-11.35^{* * *}$ & 2.569 \\
& $(8.180)$ & $(8.061)$ & $(8.116)$ & $(8.390)$ & $(3.106)$ & $(3.022)$ & $(2.478)$ & $(3.230)$ \\
AR(2) & 0.24 & 0.28 & 0.17 & 0.33 & 0.31 & 0.21 & 0.30 & 0.58 \\
Hansen (J) & 0.13 & 0.12 & 0.08 & 0.11 & 0.04 & 0.01 & 0.05 & 0.03 \\
Observations & $1,335,157$ & $1,335,157$ & $1,335,157$ & $1,335,157$ & $1,335,157$ & $1,335,157$ & $1,335,157$ & $1,335,157$ \\
\hline
\end{tabular}

Note: Columns 1-4 are for firms with negative profits. Columns 5-8 are for firms with positive profits. The dependent variable is investment rate. All estimations include full sets of two-digit industry dummies, 11-year dummies, and 8 dummies for owner education. Standard errors and test statistics are asymptotically robust to heteroskedasticity. The estimator is SGMM (xabond2 in Stata). Endogenous variables include the two institutional variables, two external financing variables, and the firm size variable. The instruments for difference equation are the lagged 3- to 4-year level-variables. The instruments for level equation are the lagged 2- to 3-year differencevariables. AR(2) is autocorrelation test under the null that there is no autocorrelation in the transformed equations. Hansen (J) is over-identification test, under the null that the overidentifying restrictions are valid, the statistic is asymptotically distributed as a chi-square variable. For display purposes, the unit of investment is percentage times 100, the unit of population density is people/m2, the unit of distance is hundred $\mathrm{km}$, and the unit of consumption is thousand VND/person. These units are different from the conventional units reported in Table1. 
Appendix 5: Alternative Separation of Business Norms

\begin{tabular}{|c|c|c|}
\hline & (1) & (2) \\
\hline \multirow[t]{2}{*}{ Local governance (PCI scores) } & $0.439 * * *$ & $0.675^{* * *}$ \\
\hline & $(0.0528)$ & $(0.105)$ \\
\hline \multirow[t]{2}{*}{ Annam (Trung Ky) } & 6.874 & $-86.70^{* *}$ \\
\hline & $(11.67)$ & $(39.51)$ \\
\hline \multirow[t]{2}{*}{ Cochinchine (Nam Ky) } & $142.5^{* * *}$ & $38.94 * *$ \\
\hline & $(12.50)$ & $(16.71)$ \\
\hline \multirow[t]{2}{*}{ Annam $\times$ Local governance } & 0.0851 & $1.863^{* * *}$ \\
\hline & $(0.167)$ & $(0.551)$ \\
\hline \multirow[t]{2}{*}{ Cochinchine $\times$ Local governance } & $-2.506^{* * *}$ & $-0.942 * * *$ \\
\hline & $(0.212)$ & $(0.286)$ \\
\hline \multirow{2}{*}{ Bank loans } & $-102.3^{* * *}$ & -14.18 \\
\hline & $(12.94)$ & $(10.42)$ \\
\hline \multirow[t]{2}{*}{ Informal loans } & $227.4^{* * *}$ & 37.42 \\
\hline & $(14.97)$ & (61.13) \\
\hline \multirow[t]{2}{*}{ Annam $\times$ Bank loans } & $182.0^{* * *}$ & \\
\hline & $(24.38)$ & \\
\hline \multirow[t]{2}{*}{ Cochinchine $\times$ Bank loans } & $211.9^{* * *}$ & \\
\hline & $(17.21)$ & \\
\hline \multirow[t]{2}{*}{ Annam $\times$ Informal loans } & & 156.2 \\
\hline & & $(217.4)$ \\
\hline \multirow[t]{4}{*}{ Cochinchine $\times$ Informal loans } & & $880.9^{* * *}$ \\
\hline & & $(79.35)$ \\
\hline & $-11.26^{* * *}$ & $-7.292 * * *$ \\
\hline & $(0.279)$ & $(0.497)$ \\
\hline \multirow[t]{2}{*}{ Firm age } & $-0.0379 * *$ & $-0.156^{* * *}$ \\
\hline & $(0.0165)$ & $(0.0384)$ \\
\hline \multirow[t]{2}{*}{ Owner gender dummy } & $-0.430 * * *$ & $-0.800 * * *$ \\
\hline & $(0.121)$ & $(0.163)$ \\
\hline \multirow[t]{2}{*}{ Owner age } & $-0.0524 * * *$ & $-0.0961^{* * *}$ \\
\hline & $(0.007)$ & $(0.009)$ \\
\hline \multirow[t]{2}{*}{ Distance } & $-49.33^{* * *}$ & -20.77 \\
\hline & $(5.445)$ & $(20.37)$ \\
\hline \multirow[t]{2}{*}{ Population density } & $70.94^{* * *}$ & $91.49^{* * *}$ \\
\hline & $(5.200)$ & $(13.29)$ \\
\hline \multirow[t]{2}{*}{ Provincial consumption } & $-43.49 * * *$ & $-37.15^{* * *}$ \\
\hline & $(2.409)$ & $(4.115)$ \\
\hline \multirow[t]{2}{*}{ Labour force } & $41.42^{* * *}$ & $84.66^{* * *}$ \\
\hline & $(7.616)$ & $(25.44)$ \\
\hline $\operatorname{AR}(2)$ & 0.47 & 0.51 \\
\hline Hansen (J) & 0.08 & 0.09 \\
\hline Observations & $1,335,157$ & $1,335,157$ \\
\hline
\end{tabular}

Note: The benchmark is the group of firms located in Tonkin (Bac Ky). The dependent variable is investment rate. All estimations include full sets of two-digit industry dummies, 11-year dummies, and 8 dummies for owner education. Standard errors and test statistics are asymptotically robust to heteroskedasticity. The estimator is SGMM (xabond2 in Stata). Endogenous variables include the two institutional variables, two external financing variables, and the firm size variable. The instruments for difference equation are the lagged 3- to 4-year level-variables. The instruments for level equation are the lagged 2- to 3-year difference-variables. AR(2) is autocorrelation test under the null that there is no autocorrelation in the transformed equations. Hansen (J) is over-identification test, under the null that the overidentifying restrictions are valid, the statistic is asymptotically distributed as a chi-square variable. For display purposes, the unit of investment is percentage times 100, the unit of population 
density is people $/ \mathrm{m} 2$, the unit of distance is hundred $\mathrm{km}$, and the unit of consumption is thousand VND/person. These units are different from the conventional units reported in Table1.

\section{Appendix 6: Alternative Measures of Business Norms}

\begin{tabular}{|c|c|c|c|c|}
\hline \multirow{3}{*}{ Local governance (PCI scores) } & (1) & (2) & (3) & (4) \\
\hline & 0.015 & -0.021 & 0.017 & $0.309^{* * *}$ \\
\hline & $(0.060)$ & $(0.053)$ & $(0.045)$ & $(0.035)$ \\
\hline \multirow[t]{2}{*}{ Bank loans } & $-3.509 * * *$ & $-2.117^{* *}$ & $-4.101^{* *}$ & 0.746 \\
\hline & $(1.252)$ & $(0.908)$ & $(1.788)$ & $(0.823)$ \\
\hline \multirow{2}{*}{ Informal loans } & $16.409^{* * *}$ & $7.790 * * *$ & $9.188^{* * *}$ & $5.647^{* * *}$ \\
\hline & $(2.514)$ & $(2.015)$ & $(1.732)$ & $(1.520)$ \\
\hline \multirow[t]{2}{*}{ No. of markets } & $0.008^{* *}$ & $0.003^{*}$ & & \\
\hline & $(0.004)$ & $(0.001)$ & & \\
\hline \multirow[t]{2}{*}{ Local governance $\times$ No. of markets } & $-0.000^{*}$ & $-0.000^{* * *}$ & & \\
\hline & $(0.000)$ & $(0.000)$ & & \\
\hline No. of Market $\times$ Bank loans & $\begin{array}{c}0.003^{* * *} \\
(0.001)\end{array}$ & & & \\
\hline No. of market $\times$ Informal loans & & $\begin{array}{c}0.002^{* * *} \\
(0.001)\end{array}$ & & \\
\hline No. of number of cargos & & & $\begin{array}{c}0.000^{* * *} \\
(0.000)\end{array}$ & $\begin{array}{c}0.000^{* * *} \\
(0.000)\end{array}$ \\
\hline Local governance $\times$ No. of cargo & & & $\begin{array}{c}-0.000^{* * *} \\
(0.000)\end{array}$ & $\begin{array}{c}-0.000^{* * *} \\
(0.000)\end{array}$ \\
\hline No. of cargo $\times$ Bank loans & & & $\begin{array}{c}0.000 \\
(0.000)\end{array}$ & \\
\hline No. of cargo $\times$ Informal loans & & & & $\begin{array}{c}0.000^{* * *} \\
(0.000)\end{array}$ \\
\hline \multirow[t]{2}{*}{ Firm size } & $-11.293^{* * *}$ & $-6.614^{* * *}$ & $-8.920^{* * *}$ & $-10.624^{* * *}$ \\
\hline & $(0.302)$ & $(0.262)$ & $(0.240)$ & $(0.171)$ \\
\hline \multirow[t]{2}{*}{ Firm age } & $-1.797^{* *}$ & -0.860 & -0.070 & $-2.089 * * *$ \\
\hline & $(0.817)$ & $(0.676)$ & $(0.512)$ & $(0.483)$ \\
\hline \multirow[t]{2}{*}{ Owner gender dummy } & 0.845 & -0.416 & $-0.790 *$ & -0.429 \\
\hline & $(0.760)$ & $(0.628)$ & $(0.474)$ & $(0.448)$ \\
\hline \multirow[t]{2}{*}{ Distance } & -234.106 & -97.748 & -64.646 & -25.636 \\
\hline & $(208.027)$ & (91.115) & $(74.228)$ & $(22.992)$ \\
\hline \multirow[t]{2}{*}{ Population density } & $-139.825^{* * *}$ & $-160.135^{* * *}$ & $-65.745^{* * *}$ & $-56.748^{* * *}$ \\
\hline & $(47.019)$ & $(39.760)$ & $(5.818)$ & $(5.781)$ \\
\hline \multirow[t]{2}{*}{ Provincial consumption } & $-37.457^{* * *}$ & $-33.591^{* * *}$ & $-21.181^{* * *}$ & $-3.190^{*}$ \\
\hline & $(4.520)$ & $(3.800)$ & $(2.211)$ & $(1.925)$ \\
\hline \multirow{2}{*}{ Labour force } & $50.347^{* * *}$ & $20.604^{* * *}$ & $47.380^{* * *}$ & $10.312^{* *}$ \\
\hline & $(7.926)$ & $(5.721)$ & $(4.656)$ & $(4.593)$ \\
\hline $\mathrm{AR}(2)$ & 0.32 & 0.38 & 0.32 & 0.18 \\
\hline Hansen (J) & 0.12 & 0.16 & 0.11 & 0.04 \\
\hline Observations & $1,335,157$ & $1,335,157$ & $1,335,157$ & $1,335,157$ \\
\hline
\end{tabular}

Note: Columns 1-2 use the number of markets as a proxy for the existence of pro-entrepreneurship norms. Columns 3-4 use the number of cargo transportations as a proxy for the existence of pro-entrepreneurship norms. The dependent variable is investment rate. All estimations include full sets of two-digit industry dummies, 11-year dummies, and 8 dummies for owner education. Standard errors and test statistics are asymptotically robust to heteroskedasticity. The estimator is SGMM (xabond2 in Stata). Endogenous variables include the two institutional variables, two external financing variables, and the firm size variable. The instruments for difference equation are the lagged 3- to 4-year level-variables. The instruments for level equation are the lagged 2- to 3-year difference-variables. AR(2) is autocorrelation test under the null that there is no autocorrelation in the transformed equations. Hansen (J) is over-identification test, under the null that the overidentifying restrictions are valid, the statistic is asymptotically distributed as a chi-square variable. For display purposes, the unit of investment is percentage 
times 100, the unit of population density is people/m2, the unit of distance is hundred $\mathrm{km}$, and the unit of consumption is thousand VND/person. These units are different from the conventional units reported in Table1.

\section{Appendix 7: Additional Control Variables}

\begin{tabular}{|c|c|c|c|c|}
\hline & (1) & (2) & (3) & (4) \\
\hline \multirow[t]{2}{*}{ Local governance (PCI scores) } & $0.086^{* * *}$ & $0.122^{* * *}$ & 0.031 & $0.153^{* * *}$ \\
\hline & $(0.026)$ & $(0.035)$ & $(0.036)$ & $(0.031)$ \\
\hline \multirow[t]{2}{*}{ Business norms (South dummy) } & $10.190^{* *}$ & $15.570^{* *}$ & 17.610 & $29.920^{* *}$ \\
\hline & $(4.006)$ & $(6.286)$ & $(14.067)$ & $(11.834)$ \\
\hline \multirow[t]{2}{*}{ Business norms $\times$ Local governance } & $-0.157^{* * *}$ & $-0.304^{* * *}$ & $-0.097 *$ & $-0.085^{* *}$ \\
\hline & $(0.037)$ & $(0.053)$ & $(0.056)$ & $(0.043)$ \\
\hline \multirow[t]{2}{*}{ Bank loans } & $-45.556^{* * *}$ & $-7.785^{* * *}$ & -0.098 & $-13.534^{* * *}$ \\
\hline & $(6.997)$ & $(0.972)$ & $(0.818)$ & $(0.912)$ \\
\hline \multirow[t]{2}{*}{ Informal loans } & $21.998^{* * *}$ & $29.544^{* * *}$ & $6.342^{* * *}$ & $4.107^{*}$ \\
\hline & $(1.277)$ & $(2.253)$ & $(1.765)$ & $(2.465)$ \\
\hline \multirow[t]{2}{*}{ Local governance $\times$ Bank loans } & $1.065^{* * *}$ & & & \\
\hline & $(0.116)$ & & & \\
\hline \multirow[t]{2}{*}{ Business norms $\times$ Bank loans } & & $14.467^{* * *}$ & & \\
\hline & & $(1.441)$ & & \\
\hline \multirow[t]{2}{*}{ Local governance $\times$ Informal loans } & & & $0.143^{* * *}$ & \\
\hline & & & $(0.044)$ & \\
\hline \multirow[t]{2}{*}{ Business norms $\times$ Informal loans } & & & & $54.168^{* * *}$ \\
\hline & & & & $(4.589)$ \\
\hline \multirow[t]{2}{*}{ Firm size } & $-12.589 * * *$ & $-12.561^{* * *}$ & $-6.985^{* * *}$ & $-13.059^{* * *}$ \\
\hline & $(0.128)$ & $(0.205)$ & $(0.279)$ & $(0.206)$ \\
\hline \multirow[t]{2}{*}{ Firm age } & $0.612^{*}$ & $-1.966^{* * *}$ & 0.150 & $-1.819^{* * *}$ \\
\hline & $(0.335)$ & $(0.571)$ & $(0.608)$ & $(0.550)$ \\
\hline \multirow[t]{2}{*}{ Owner age } & 0.194 & $1.186^{* *}$ & -0.298 & $1.076^{* *}$ \\
\hline & $(0.280)$ & $(0.479)$ & $(0.535)$ & $(0.478)$ \\
\hline \multirow[t]{2}{*}{ Distance } & $-117.329^{* * *}$ & $-168.659^{* *}$ & -36.660 & $-232.236^{* * *}$ \\
\hline & $(30.424)$ & (82.389) & $(59.434)$ & $(88.856)$ \\
\hline \multirow[t]{2}{*}{ Population density } & $-55.020^{* * *}$ & $-103.505^{* * *}$ & $-130.109^{* * *}$ & $-186.977^{* * *}$ \\
\hline & $(6.236)$ & $(33.181)$ & $(49.979)$ & $(33.635)$ \\
\hline \multirow[t]{2}{*}{ Provincial consumption } & $-35.441^{* * *}$ & $-24.833^{* * *}$ & $-13.173^{* * *}$ & $-33.458^{* * *}$ \\
\hline & $(1.962)$ & $(3.441)$ & $(3.948)$ & $(3.485)$ \\
\hline \multirow[t]{2}{*}{ Labour force } & $37.009^{* * *}$ & $28.886^{* * *}$ & 7.151 & $36.482^{* * *}$ \\
\hline & $(4.127)$ & $(6.600)$ & $(6.787)$ & $(6.498)$ \\
\hline $\mathrm{AR}(2)$ & 0.22 & 0.28 & 0.19 & 0.26 \\
\hline Hansen (J) & 0.04 & 0.05 & 0.04 & 0.03 \\
\hline Observations & $1,335,157$ & $1,335,157$ & $1,335,157$ & $1,335,157$ \\
\hline
\end{tabular}

Note: The dependent variable is investment rate. All estimations include full sets of two-digit industry dummies, 11-year dummies, 6 regional dummies, a set of the interaction terms between year dummies and industry dummies, a set of the interaction terms between regional dummies and year dummies, and 8 dummies for owner education. Standard errors and test statistics are asymptotically robust to heteroskedasticity. The estimator is SGMM (xabond2 in Stata). Endogenous variables include the two institutional variables, two external financing variables, and the firm size variable. The instruments for difference equation are the lagged 3- to 4-year level-variables. The instruments for level equation are the lagged 2- to 3-year difference-variables. AR(2) is autocorrelation test under the null that there is no autocorrelation in the transformed equations. Hansen (J) is over-identification test, under the null that the overidentifying restrictions are valid, the statistic is asymptotically distributed as a chi-square variable. For display purposes, the unit of investment is percentage times 100, the unit of population density is people $/ \mathrm{m} 2$, the unit of distance is hundred $\mathrm{km}$, and the unit of consumption is thousand VND/person. These units are different from the conventional units reported in Table1. 
Appendix 8: Before and After the 2008 Crisis

\begin{tabular}{|c|c|c|c|c|c|c|c|c|}
\hline \multirow{4}{*}{ Local governance (PCI scores) } & (1) & (2) & (3) & (4) & (5) & (6) & (7) & (8) \\
\hline & $\begin{array}{c}\text { Before } \\
\text { crisis }\end{array}$ & $\begin{array}{c}\text { Before } \\
\text { crisis }\end{array}$ & $\begin{array}{c}\text { Before } \\
\text { crisis }\end{array}$ & $\begin{array}{c}\text { Before } \\
\text { crisis }\end{array}$ & $\begin{array}{l}\text { After } \\
\text { crisis }\end{array}$ & $\begin{array}{l}\text { After } \\
\text { crisis }\end{array}$ & $\begin{array}{l}\text { After } \\
\text { crisis }\end{array}$ & $\begin{array}{l}\text { After } \\
\text { crisis }\end{array}$ \\
\hline & 1.950 & 1.542 & 0.849 & 0.670 & -0.0403 & $1.117^{* * *}$ & $0.443^{* * *}$ & -0.0808 \\
\hline & (1.239) & $(1.022)$ & $(0.576)$ & $(1.820)$ & $(0.106)$ & $(0.0940)$ & $(0.0409)$ & $(0.463)$ \\
\hline \multirow[t]{2}{*}{ Business norms (South dummy) } & 78.60 & 46.54 & $92.58^{* * *}$ & $232.7^{*}$ & $50.12^{* * *}$ & $22.27^{* *}$ & $126.3^{* * *}$ & -21.08 \\
\hline & $(51.52)$ & $(55.19)$ & $(32.47)$ & $(119.5)$ & $(10.19)$ & $(11.33)$ & $(6.089)$ & $(47.86)$ \\
\hline \multirow[t]{2}{*}{ Business norms $\times$ Local governance } & $-1.348^{*}$ & -0.843 & $-1.562^{* * *}$ & $-3.019 * *$ & $-0.850^{* * *}$ & $-0.596^{* * *}$ & $-2.090^{* * *}$ & 0.193 \\
\hline & $(0.806)$ & $(0.704)$ & $(0.553)$ & $(1.504)$ & $(0.169)$ & $(0.188)$ & $(0.100)$ & $(0.823)$ \\
\hline \multirow[t]{2}{*}{ Bank loans } & 503.3 & 27.96 & $330.0^{* * *}$ & 126.3 & $-837.5^{* * *}$ & $-57.24^{* * *}$ & $26.25^{* * *}$ & -50.93 \\
\hline & (489.7) & $(172.4)$ & $(37.93)$ & $(321.4)$ & $(73.81)$ & (18.49) & $(1.060)$ & (51.51) \\
\hline \multirow[t]{2}{*}{ Informal loans } & $424.5^{* *}$ & $347.1^{* *}$ & 622.7 & $857.7^{* *}$ & $97.50^{* *}$ & $167.1^{* * *}$ & $-97.82 *$ & 340.5 \\
\hline & $(189.4)$ & $(135.9)$ & $(675.0)$ & $(359.1)$ & $(47.40)$ & $(53.26)$ & $(50.11)$ & $(261.6)$ \\
\hline \multirow[t]{2}{*}{ Local governance $\times$ Bank loans } & & -21.53 & & & & $196.7^{* * *}$ & & \\
\hline & & $(186.5)$ & & & & $(16.41)$ & & \\
\hline \multirow[t]{2}{*}{ Business norms $\times$ Bank loans } & -10.08 & & & & $14.85^{* * *}$ & & & \\
\hline & (9.903) & & & & $(1.167)$ & & & \\
\hline \multirow[t]{2}{*}{ Local governance $\times$ Informal loans } & & & -11.01 & & & & $1.939 * *$ & \\
\hline & & & $(12.12)$ & & & & $(0.835)$ & \\
\hline \multirow[t]{2}{*}{ Business norms $\times$ Informal loans } & & & & $-1,376^{*}$ & & & & $977.2^{* * *}$ \\
\hline & & & & $(736.8)$ & & & & $(259.0)$ \\
\hline \multirow[t]{2}{*}{ Firm size } & -6.876 & $-8.902^{* * *}$ & $-17.32^{* * *}$ & $-8.931^{*}$ & $-7.597^{* * *}$ & $-7.610^{* * *}$ & $-12.71^{* * *}$ & $-6.224^{* * *}$ \\
\hline & (4.195) & $(2.969)$ & $(0.908)$ & (5.057) & $(0.414)$ & $(0.440)$ & $(0.143)$ & $(1.422)$ \\
\hline \multirow[t]{2}{*}{ Firm age } & -0.255 & -0.121 & $0.270^{* * *}$ & -0.118 & $-0.223^{* * *}$ & $-0.229 * * *$ & $-0.0475^{* * *}$ & $-0.164^{* * *}$ \\
\hline & $(0.280)$ & $(0.185)$ & $(0.0490)$ & $(0.335)$ & $(0.0181)$ & $(0.0192)$ & $(0.0136)$ & $(0.0491)$ \\
\hline \multirow[t]{2}{*}{ Owner gender dummy } & 0.112 & 0.0234 & -0.320 & 0.838 & $-0.394^{* * *}$ & $-0.252^{*}$ & $-0.584^{* * *}$ & -0.186 \\
\hline & $(0.400)$ & $(0.399)$ & $(0.305)$ & $(0.704)$ & $(0.126)$ & $(0.135)$ & $(0.117)$ & $(0.254)$ \\
\hline \multirow[t]{2}{*}{ Owner age } & $-0.0464^{* *}$ & $-0.0397^{* *}$ & -0.0103 & -0.0525 & $-0.0482^{* * *}$ & $-0.0482^{* * *}$ & $-0.0219 * * *$ & $-0.0903^{* * *}$ \\
\hline & $(0.0229)$ & $(0.0190)$ & $(0.0158)$ & $(0.0326)$ & $(0.00702)$ & $(0.00743)$ & $(0.00622)$ & $(0.0150)$ \\
\hline \multirow[t]{2}{*}{ Distance } & 21.07 & 31.81 & $-29.62^{* * *}$ & -36.58 & $-16.30 * * *$ & $-13.94^{* * *}$ & $-31.81^{* * *}$ & 6.047 \\
\hline & $(43.04)$ & $(40.68)$ & $(8.801)$ & $(76.76)$ & $(2.156)$ & $(2.353)$ & $(0.939)$ & $(11.26)$ \\
\hline \multirow[t]{2}{*}{ Population density } & 2.367 & 14.79 & 9.521 & -46.25 & $-8.746^{* * *}$ & 2.075 & $-8.507^{* * *}$ & 6.548 \\
\hline & $(16.22)$ & $(24.88)$ & $(5.979)$ & $(36.61)$ & $(2.386)$ & $(2.964)$ & $(1.345)$ & $(9.231)$ \\
\hline Provincial consumption & $42.27^{* * *}$ & $47.10^{* * *}$ & $56.40^{* * *}$ & $68.05^{* * *}$ & $-12.23^{* * *}$ & $-15.51^{* * *}$ & $-15.55^{* * *}$ & -0.563 \\
\hline
\end{tabular}




$\begin{array}{rcccccccc} & (15.91) & (14.04) & (6.892) & (24.13) & (1.660) & (1.989) & (1.170) & (4.123) \\ \text { Labour force } & 39.90^{* *} & 33.79^{* *} & -4.380 & 35.72 & -16.73^{* * *} & -0.318 & -40.76^{* * *} & 48.34^{* * *} \\ & (19.15) & (13.96) & (5.953) & (26.15) & (3.956) & (4.157) & (2.667) & (18.20) \\ \text { AR(2) } & 0.37 & 0.31 & 0.33 & 0.47 & 0.52 & 0.25 & 0.22 & 0.38 \\ \text { Hansen (J) } & 0.17 & 0.03 & 0.05 & 0.05 & 0.09 & 0.11 & 0.05 & 0.06 \\ \text { Observations } & 1,335,157 & 1,335,157 & 1,335,157 & 1,335,157 & 1,335,157 & 1,335,157 & 1,335,157 & 1,335,157\end{array}$

Note: Columns 1-4 are for the period before the 2008 financial crisis. Columns 5-8 are for the period after the 2008 financial crisis. The dependent variable is investment rate. All estimations include full sets of two-digit industry dummies, 11-year dummies, 6 regional dummies, a set of the interaction terms between year dummies and industry dummies, a set of the interaction terms between regional dummies and year dummies, and 8 dummies for owner education. Standard errors and test statistics are asymptotically robust to heteroskedasticity. The estimator is SGMM (xabond2 in Stata). Endogenous variables include the two institutional variables, two external financing variables, and the firm size variable. The instruments for difference equation are the lagged 2- to 3-year level-variables. The instruments for level equation are the lagged 1- to 2-year difference-variables. AR(2) is autocorrelation test under the null that there is no autocorrelation in the transformed equations. Hansen (J) is over-identification test, under the null that the overidentifying restrictions are valid, the statistic is asymptotically distributed as a chi-square variable. For display purposes, the unit of investment is percentage times 100 , the unit of population density is people/m2, the unit of distance is hundred $\mathrm{km}$, and the unit of consumption is thousand VND/person. These units are different from the conventional units reported in Table 1 